DEPARTMENT OF THE INTERIOR

U.S. GEOLOGICAL SURVEY

Preliminary Geologic Map of the Thaniyat Turayf Quadrangle, sheet 29C, Kingdom of Saudi Arabia

by

C.R. Meissner 1/, Jr., S.M. Dini, A.M. Farasani, G.P. Riddler,

G.H. Smith, M.B. Griffin, and Marcel Van Eck

Open-File Report $90-259$

Report prepared by the U.S. Geological Survey in cooperation with the Deputy Ministry for Mineral Resources, Saudi Arabia

This report is preliminary and has not been reviewed for conformity with U.S. Geological Survey editorial standards and stratigraphic nomenclature.

1/ U.S. Geological Survey 


\section{CONTENTS}

Page

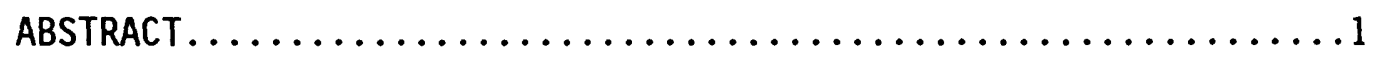

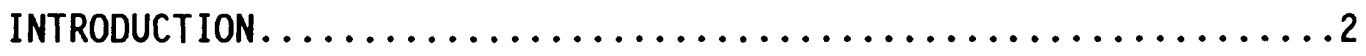

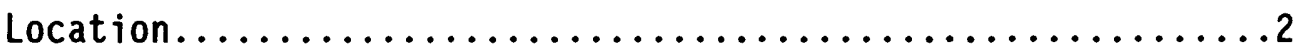

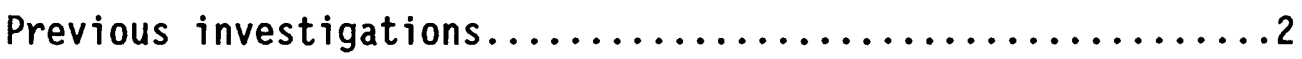

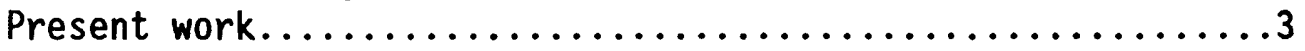

Acknowledgments.........................

GEOLOGIC SETTING..........................

PHANEROZOIC SEDIMENTARY ROCKS ...................4

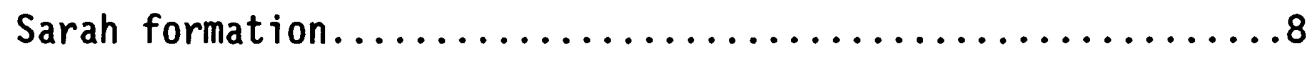

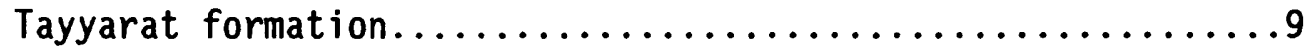

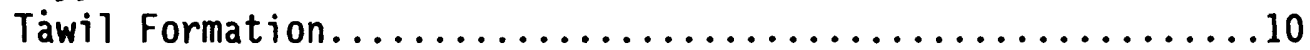

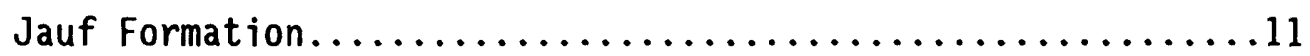

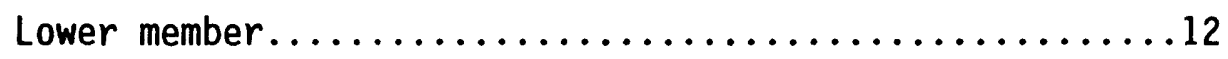

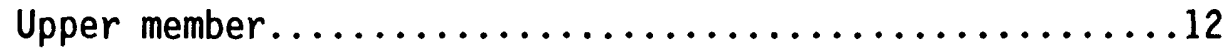

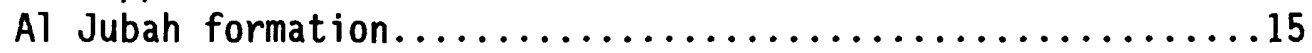

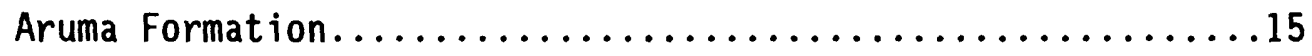

Zallum member and undifferentiated Cretaceous rocks....15

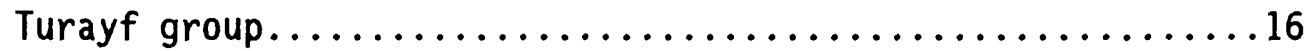

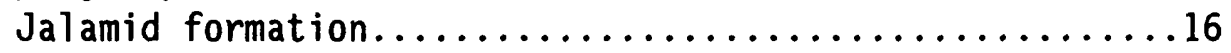

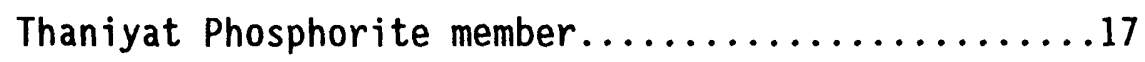

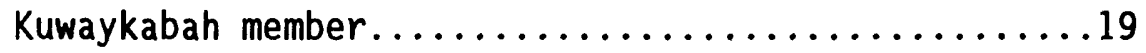

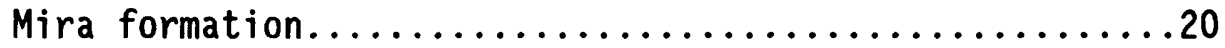

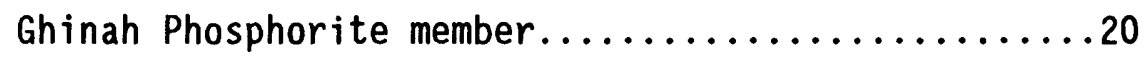

Hawsa, Mindassah, and Sib members, undivided......20

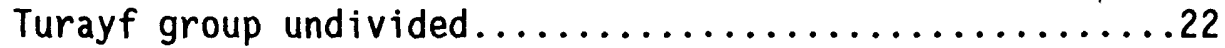

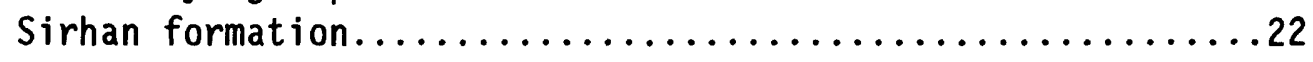

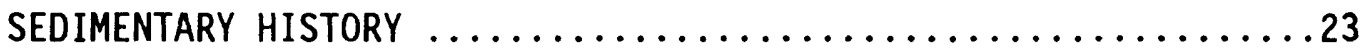

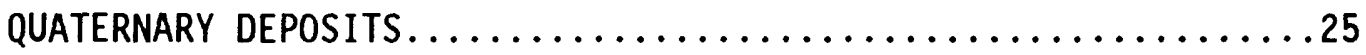

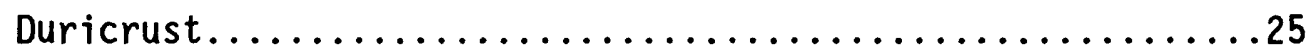

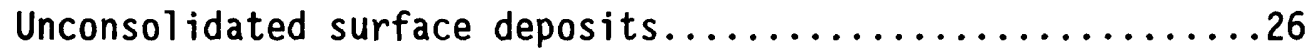

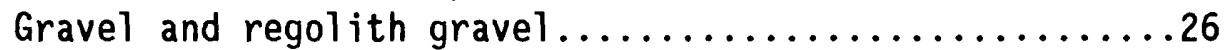

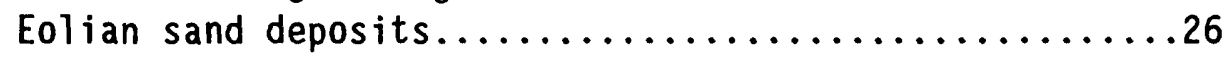

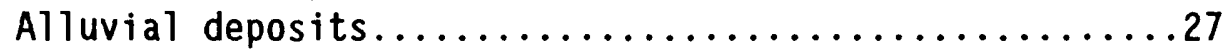

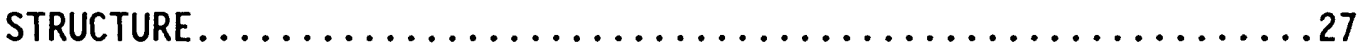


ECONOMIC GEOLOGY...................................

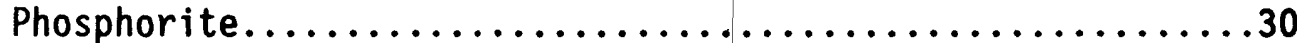

Than iyat Phosphorite member.......................30

Ghinah Phosphorite member.........................

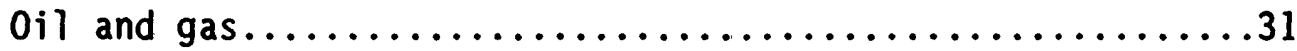

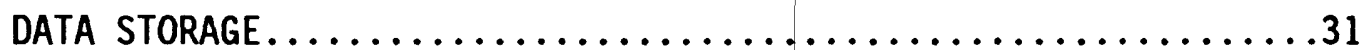

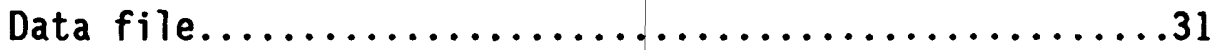

Mineral Occurrence Documentation System..............31

REFERENCES CITED.................................

\section{ILLUSTRATIONS}

[Plate in pocket]

Plate 1. Geologic map of the Thaniyat Turayf quadrangle, sheet 29C, Kingdom of Saudi Arabia.

Figure 1. Location map of the Thaniyat Turayf quadrangle and surrounding area.......................

Figure 2. Generalized stratigraphic column of rocks in the Thaniyat Turayf quadrangle..............6

Figure 3. Measured section of the Jauf and $A 1$ Juba formations in the vicinity of Al Jiraniyat......13

Figure 4. Measured section (DF 9) of the Ja'alat as Sawda escarpment, Thaniyat Turayf quadrangle.........14

Figure 5. Measured section at site of USGS adit (WG 104), Thaniyat escarpment, Thaniyat Turayf quadrangle............................ 18

Figure 6. Close-up view of the USGS adit in the basal phosphorite bed of the Thaniyat Phosphorite member................................19 


\title{
PRELIMINARY GEOLOGIC MAP OF THE THANIYAT TURAYF QUADRANGLE, SHEET 29 C, KINGDOM OF SAUDI ARABIA
}

\author{
By \\ C. R. MEISSNER, Jr., S. M. DINI, A. M. FARASANI \\ G. P. RIDDLER, G. H. SMITH, M. B. GRIFFIN, \\ AND MARCEL VAN ECK
}

\begin{abstract}
The Thaniyat Turayf quadrangle, sheet 29 , lies in the northwestern part of Saudi Arabia near the border with Jordan. The quadrangle is located between lat $29^{\circ} 00^{\prime}-30^{\circ} 00^{\prime} \mathrm{N}$. and long $37^{\circ} 30^{\prime}-39^{\circ} 00^{\prime}$ E. It includes the southwestern rim of the Sirhan-Turayf Basin and is underlain by Silurian to Miocene-Pliocene sedimentary rocks that are partly covered by surficial duricrust, sand, and gravel.

Most of the sedimentary rocks of the map area are of marine origin, varying from outer shelf to near-shore and coastal-lagoon environments. Episodes of fluvial-deltaic deposition reflecting marine regression occurred in the Devonian, and continental and lacustrine sedimentation are characteristic of the Miocene.

Tensional structures, such as linear-joint fractures, grabens, and block faulting, probably resulted from rifting associated with the opening of the Red Sea.

The map area contains the southern part of the Southwestern Area, an important phosphate-rock province that includes the Thaniyat Phosphorite member. Total estimated resources of phosphorite in three select areas of the Thaniyat Phosphorite member are 978,000,000 $t$ with an average grade of 24 percent $\mathrm{P}_{2} \mathrm{O}_{5}$.

A new structural concept introduced in this report extends the Wadi as Sirhan graben complex southeastward into the An Nafud. This concept increases the size of the potentially oil-and-gas-bearing Wadi as Sirhan region to include the An Nafud.
\end{abstract}




\section{INTRODUCTION}

\section{LOCATION}

The Thaniyat Turayf quadrangle, sheet $29 \mathrm{C}$, is located in the northwestern part of the Kingdom of Saudi Arabia, about $900 \mathrm{~km}$ north of Jeddah. The quadrangle lies between lat $29^{\circ} 00^{\prime}-30^{\circ} 00^{\prime} \mathrm{N}$. and long $37^{\circ} 30^{\prime}-39^{\circ} 00^{\prime} \mathrm{E}$. (fig. 1); it includes part of of Saudi Arabia's western border with the Hashemite Kingdom of Jordan.

The quadrangle contains the southwestern rim of the Sirhan-Turayf basin and includes the southern part of an area that contains phosphate-bearing rocks known as the Southwestern Area. Located in the northwestern part of the quadrangle, the Southwestern Area is a deeply dissected plateau comprising hills of moderate relief cut by several large wadis. The Thaniyat escarpment, with a relief of approximately $100 \mathrm{~m}$, forms the southern limit of the Southwestern Area and contains exposures of the Thaniyat Phosphorite member. The southern part of the Al Busayta plain is located to the east of the Southwestern Area and merges eastward with a part of the Wadi As Sirhan depression (Al Qasa'im).

The southwestern rim of the Sirhan-Turayf basin extends from the Thaniyat escarpment in the west, through Jabal Wailah, Ja'alat ash Shahba, and Ja'alat as Sawda in the central part of the study area, to Umm Juthjath and Khabb al Jamal on the eastern border of the quadrangle. A variety of terrains are present south of the basin rim: Al 'Urayq is a dune-desert arm of the An Nafud that protrudes from the east; Al Huj, located in the south-central part of the quadrangle, is a relatively low plateau broken by scattered buttes amd mesas; Mughayra is a vast, desolate area characterized by long linear sandstone ridges between the southern reach of Wadi Fajr and the western border of the quadrangle. The rugged, mountainous front of At Tubayq is located along the northwestern border of the quadrangle.

The Thaniyat Turayf quadrangle is sparsely populated. The recently constructed Tabuk to Al Jawf highway runs northeastward across the quadrangle; two small communities have been constructed near fueling stations. The community of Mughayra (from which the Mughayra area gets its name), located in the desolate western part of the quadrangle, contains a few abandoned huts and a small police post. The quadrangle is otherwise unpopulated, except during periodic traverses by bedouins.

\section{Previous Investigations}

Bramkamp and others (1963) mapped the geology of the area at a scale of $1: 500,000$. The sedimentary geology of the region is described by Powers and others 
(1966) in a report that encompasses the sedimentary geology of Saudi Arabia.

Mytton (1966) discovered phosphate rock along the Thaniyat escarpment and briefly described its occurrence. Cathcart (1966) was sent a number of friable phosphorite samples from the Thaniyat area and described their texture, composition, and amenability to beneficiation. Meissner (1967) conducted detailed investigations along the Thaniyat escarpment that revealed the prime phosphate-bearing area (West Thaniyat) and recommended a drilling program. Drilling, trenching, bulk sampling, estimation of tonnage, and submittal of samples for mineral-processing tests were done by Meissner and Ankary (1972b). Meissner and Ankary (1971, 1972a) also completed six 1:25,000-scale 7.5-minute orthophoto geologic maps of that part of the Thaniyat escarpment that lies within the Southwestern Area.

Bigot (1970) mapped and prospected in the $\mathrm{Al} \mathrm{Huj} \mathrm{area,} \mathrm{and} \mathrm{preliminary}$ investigations of availabiltiy of water for developing the phosphate deposits were conducted by Torrent (1976). Petromin-Graenges International Mining (unpublished data) examined the Thaniyat phosphate area and estimated resources.

In 1976, Riofinex Limited was requested by the Directorate General of Mineral Resources (DGMR) to undertake a phosphate resource assessement of the Sirhan-Turayf region including parts of the Thaniyat Turayf quadrangle. Several Riofinex reports were published describing the Cretaceous and Tertiary phosphate-bearing rocks. These reports include Futyan and Nicholson (1979), Bayliss (1981, 1982, 1983), Kluyver and others (1981), Riddler and van Eck (1984), and Riddler and others $(1983 ; 1984)$. Reports by Riofinex that cover the geology and phosphorite resources of parts of the map area are Smith (1983), Griffin and others (1984), and Riddler and others (1986).

\section{Present Work}

The northern half of the geologic map of the Thaniyat Turayf quadrangle (pl. 1) was compiled chiefly from unpublished data acquired by Riofinex. The data include twelve 1:50,000-scale maps and part of one 1:250.000-scale map produced by Riofinex as part of its phosphate resource assessment. The maps are stored in Riofinex Data File RF-DF-00-5. Additional data for the Al Busayta plain-Wadi as Sirhan area and much of the southern part of the quadrangle was from mapping done by the U.S. Geological Survey (USGS) for the present study during April, 1987.

The lithostratigraphic framework of the Late Cretaceous-Tertiary rocks (the Turayf group) was established by Riofinex (Riddler and others, 1984); the description of the pre-Tertiary rocks and post-Turayf group Tertiary rocks was done by the USGS. The lithostratigraphic nomenclature is in accordance with the DGMR Stratigraphic Code, but many names are new and not yet formalized. 


\section{ACKNOWLEDGments}

The authors wish to express appreciation for the sample preparation and analyses of ironstone samples performed by I. M. Naqvi, M. A. Basheer, and M. A. Hussain of the U.S. Geological Survey laboratories.

The authors also wish to express appreciation and thanks for the outstanding field support provided by the U. S. Geological Survey Field Services office, the former Riofinex Geological Mission, and Special Flights Services of the Directorate General of Mineral Resources.

\section{GEOLOGIC SETTING}

The Thaniyat Turayf quadrangle includes part of the Sirhan-Turayf basin of northwestern Saudi Arabia (fig. 1; plate 1). The Sirhan-Turayf Basin is a complex sedimentary basin that extends north and west into Iraq and Jordan. Sedimentary rocks in this basin range in age from Cambrian to Recent and have a maximum thickness of at least 2,300 m (Powers and others, 1966). The northern third of the Thaniyat Turayf quadrangle includes the southwestern rim of the basin where Cretaceous and Tertiary rocks dip northeastward toward the basin axis occupied by the Wadi as Sirhan graben complex.

The southern part of the quadrangle consists mostly of gently northeast-dipping to flat-lying Silurian and Devonian rocks that are in unconformable contact with the Cretaceous and Tertiary rocks at the rim of the Sirhan-Turayf Basin. The south-central part of the quadrangle contains part of a regional sag that is occupied by the Devonian Jauf Formation. A large arm of An Nafud (Al 'Urayq), the second largest dune desert in Saudi Arabia after the Rub Al Khali, protrudes into the map area from the southeast.

Prominent linear sandstone ridges and long joint fractures, probably related to rifting of the Red Sea, are visible on Landsat imagery and aerial photographs, and many can be traced on the surface

\section{PHANEROZOIC SEDIMENTARY ROCKS}

Exposed Phanerozoic deposits in the quadrangle include units with Late Ordovician-Early Silurian, Early Devonian, Late Cretaceous, Tertiary, and Quaternary ages (fig. 2) that are described from surface mapping, outcrop sections, and shallow-drill-hole data. Subsurface rocks in the Wadi as Sirhan graben (see cross-section A-A', fig. 1) range in age from Silurian to Tertiary and are projected from a deep drill hole (S-460) located a few kilometers to the north of the quadrangle boundary in the adjacent Wadi as Sirhan quadrangle. 

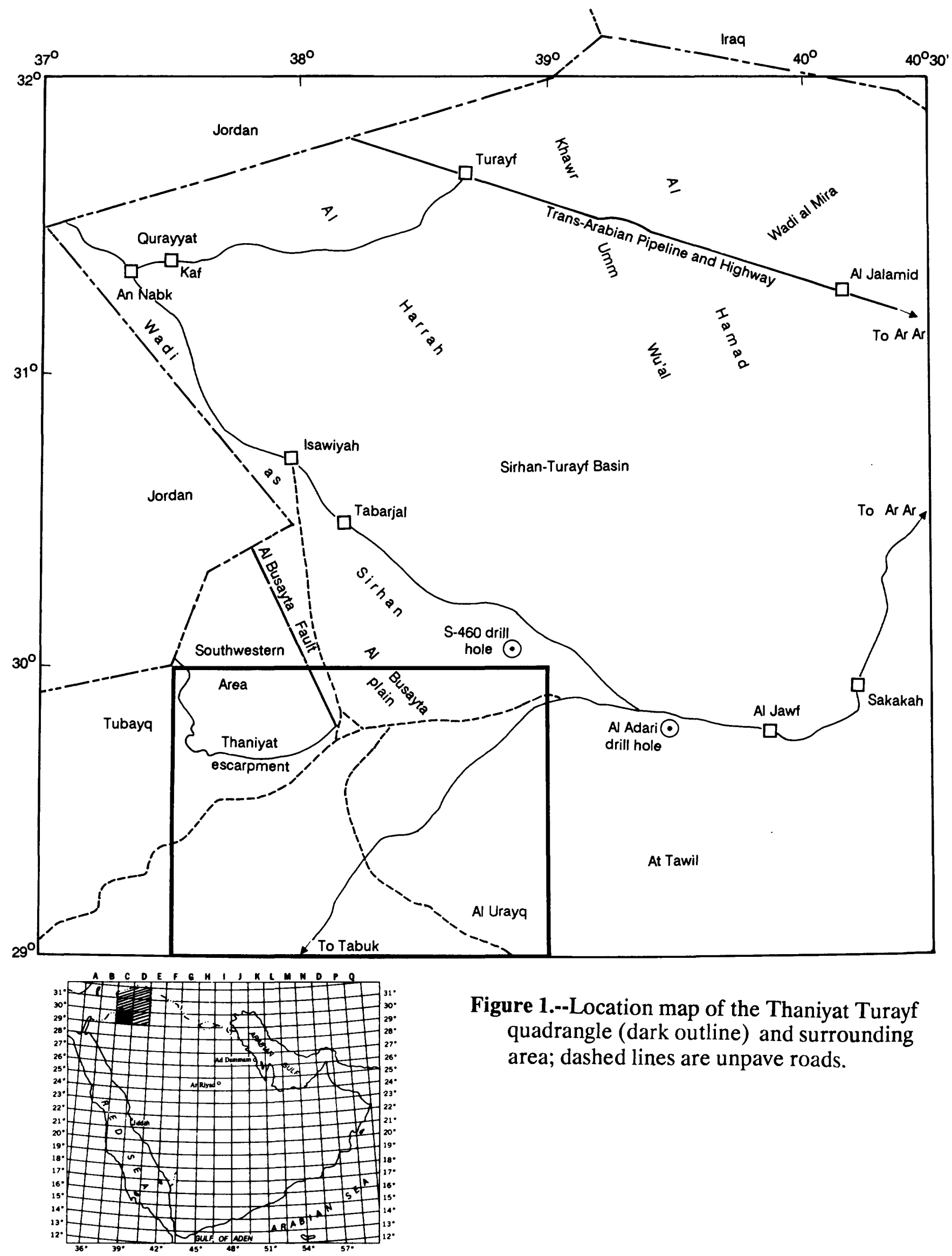

Figure 1.--Location map of the Thaniyat Turayf quadrangle (dark outline) and surrounding area; dashed lines are unpave roads. 


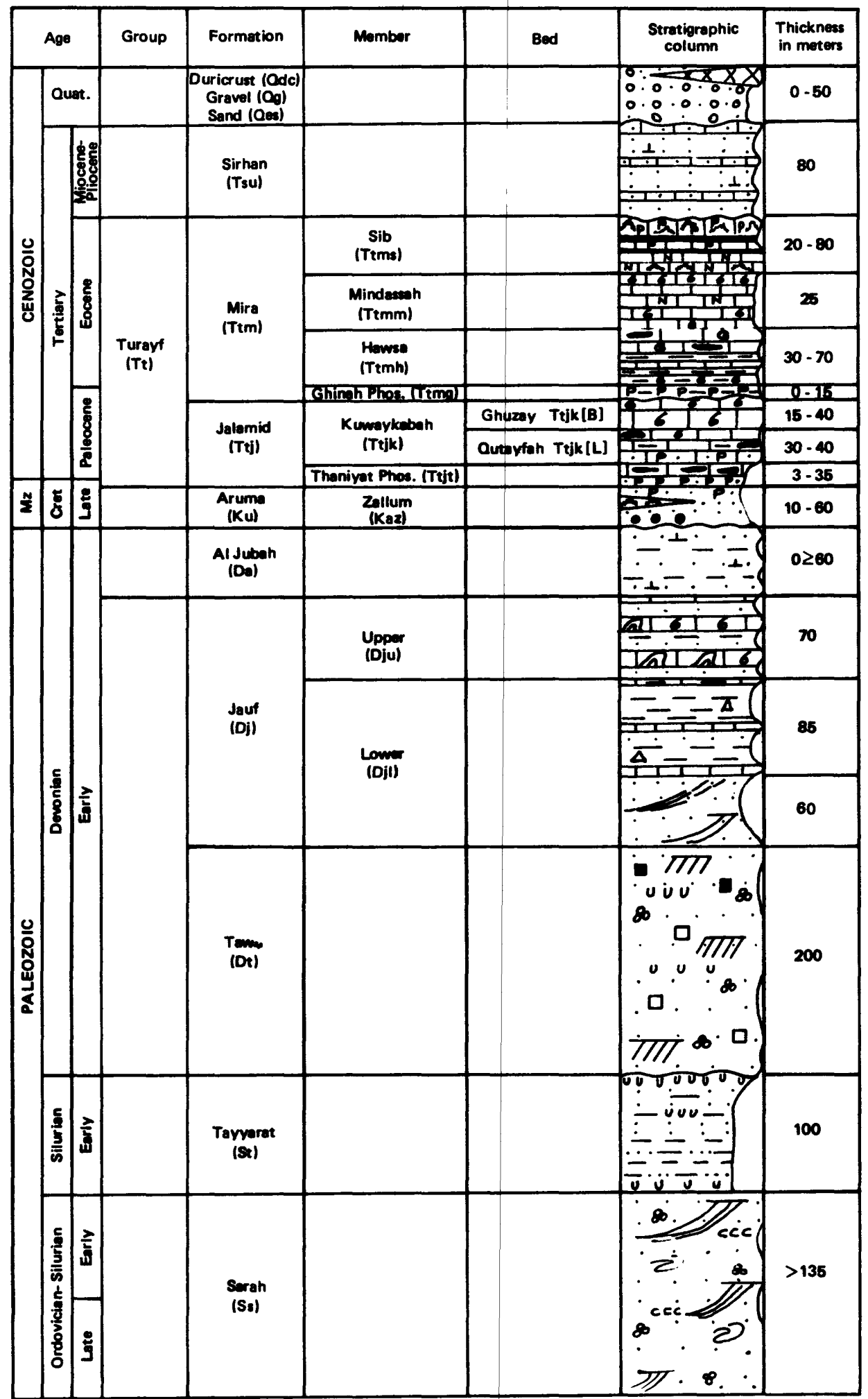

Figure 2.--Generalized stratigraphic column of rocks in the Thaniyat Turayf quadrangle showing weathering profile. 
EXPLANATION

[Figures 2, 3, 4, 5, and 6]

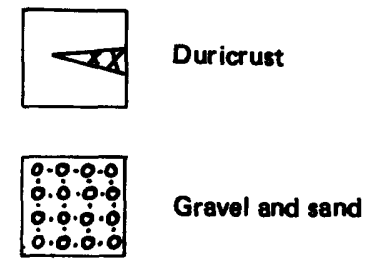

Cobbles $\left[\begin{array}{l}\dot{1} \cdot \\ \dot{1} \cdot \dot{1}\end{array}\right.$

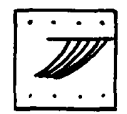

Lowengle crossbedding

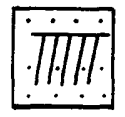

Highengle crose-
bedding

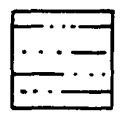

Siltstone

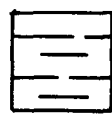

Shale and claystone

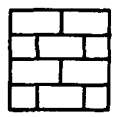

Limestone

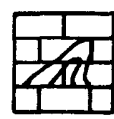

\section{Stromatolitic} limestone

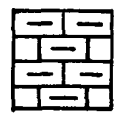

Argillaceous
limestone
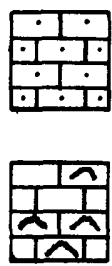

Siliceous limestone
Sandy limestone
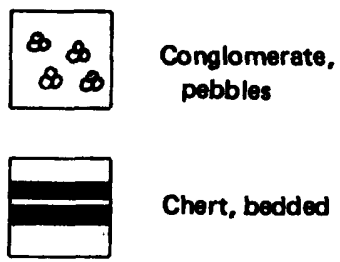

Chert, bedded

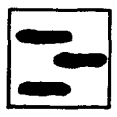

Chert, nodules, and lenses

666
666 $\quad$ Bioclastic rock

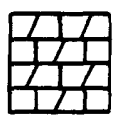

Dolomitic limestone

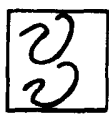

Convolute bedding

\begin{tabular}{ll}
\hline$P P P$ \\
$P P P$
\end{tabular}$\quad \begin{aligned} & \text { Phosphatic rock; } \\
& \text { Phosphorite }\end{aligned}$

NNN
$N N N$$\quad$ Nummulitic

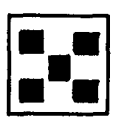

Ferruginous

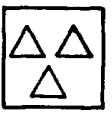

Gypsiferows

GGG

GG $G$

Geodes

UUण
UUU

Scollthus sp. trace fossils 


\section{SaRaH Formation}

The oldest rocks in the map area are tentatively classified as part of the Late Ordovician-Early Silurian Sarah formation (Ss) or its equivalent. The Sarah formation has not been described previously in the area, where Bramkamp and others (1963) show undivided Ordovician-Silurian-Devonian rocks of the Tabuk Formation. The Tabuk Formation, described by Powers and others (1966) and Powers (1968), was subdivided and reclassified by Vaslet (1987), who introduced new nomenclature for the early Paleozoic rocks of Saudi Arabia. The upper and middle parts of the former Tabuk Formation now comprise the Sarah, Tayyarat, and Tawil formations, of which the Sarah and Tayyarat are new names. Identification of the Sarah formation in the Thaniyat Turayf quadrangle is based solely on its lithologic appearance and stratigraphic position (below the Tayyarat and Tawil formations); its age has not been confirmed by diagnostic fossils.

The Sarah formation (originally named "Sarah member" of the Tabuk Formation by Clark-Lowes, 1980) is named after Sarah ridge northwest of Buraydah, where it consists mainly of sandstone that displays glacial features (Vaslet, 1987). Rocks mapped as Sarah in the Thaniyat Turayf quadrangle are the same as those mapped as the "Yellow sandstone" unit of the Tabuk Formation by Smith (1983).

The Sarah formation occupies the southwestern corner of the quadrangle. It consists of yellowish-brown sandstone that weathers to reddish brown and dark gray. It is poorly sorted and is composed of a mixture of fine to very coarse quartz grains and contains layers of grit and pebble conglomerate. The sandstone is thick bedded to massive and contains large, low-angle cross beds. Convolute bedding in the sandstone indicates that localized intraformational slumping occurred during deposition. The terrain underlain by rocks of the Sarah formation is a hummocky jumble of ragged hills and many isolated sandstone pinnacles that stand 3 to $6 \mathrm{~m}$ high. Long, very narrow, straight sandstone ridges are common; they are as much as $20 \mathrm{~m}$ high and have a preferred N. $25^{\circ}$ W. orientation. Fucoidal horizontal burrows and Cruziana sp. trace fossils have been found in the formation.

The thickness of the Sarah formation in the quadrangle is unknown. There are no outcrops from which a vertical section can be constructed. A barely perceptible east-northeast regional dip is too slight to be measured accurately, but is estimated to be less than a half degree. Using a dip of $0.33^{\circ}$ and an outcrop width of $23,000 \mathrm{~m}$, the maximum exposed thickness of the Sarah in the quadrangle is deduced (by triangulation) to be about $135 \mathrm{~m}$.

In contrast to features described by Vaslet (1987) in central and northern Saudi Arabia, the Sarah formation showed no signs of glaciation in the Thaniyat Turayf quadrangle. This may be because the area was too far to the northeast to be affected by the advancing ice cap or glacial deposition (the Late Ordovician polar ice cap is believed to have been located south of the Sahara desert). Smith (1983) attributed the poor sorting of the sandstone and the considerable variation in the angularity of 
its grains to a littoral environment of deposition. The presence of Cruziana sp. trace fossils suggests deposition in the neritic zone, which is a part of the marine littoral zone under its old definition. The contact with the overlying Tayyarat formation appears to be conformable.

\section{Tayyarat Formation}

The Tayyarat formation (St), a new subdivision of the former Tabuk Formation of Powers and others (1966), and Powers (1968), was named by Vaslet (1987) after Khashm Tayyarat in central Saudi Arabia. At Khashm Tayyarat, its type locality, the formation is $187 \mathrm{~m}$ thick and consists of two members: the lower Qusaiba member and upper Sharawra member. The two members of the Tayyarat formation have not been mapped in the Thaniyat Turayf quadrangle. In the type area, the Qusaiba member is predominantly claystone with interbeds of siltstone and micaceous fine-grained sandstone in its upper part. The Sharawra member is mainly well-bedded sandstone and shows signs of bioturbation (bore marks) on the upper surfaces of its beds. According to Vaslet (1987), both members are of marine origin, varying from strand to outer-shelf environments. The formation is dated as Early Silurian (Middle to Late Llandoverian) in central Saudi Arabia.

The Tayyarat formation in the map area is the geologic unit that Smith (1983) referred to as the "Purple sandstone and shale" unit of the Tabuk Formation. It crops out in a wide band across the southwest corner of the quandrangle and occurs in an area of "windows" exposed by erosion in the overlying Tawil formation farther east. The Tayyarat formation is composed of sandstone and, particularly near its base, subordinate beds of siltstone and shale. As the formation weathers, it takes on a purplish cast and its color varies from dark reddish brown or gray to dark purple. Overall, the sandstone is fine to medium grained and medium to thick bedded. However, in places, the sandstone contains coarse sand grains and grit layers, and is argillaceous, partly shaly, and friable. A section was measured in the At Tubayq scarp (at the west-central border of the quadrangle) that contains $97 \mathrm{~m}$ of Tayyarat rocks from the contact of the formation with the overlying Tawil formation to its base at the foot of the scarp. Intervals of Scolithus-like vertical burrows are present at the base of the section and in several intervals near the top. The top of the section, in contact with the Tawil, contains abundant vertical burrows that weather out at the surface as dark tubes. These tubes, a few centimeters high, stand out in randomly arranged rows and consist of ferruginous material from the sides of the burrows that is more resistant to weathering than the enclosing sandstone.

Numerous shallow depressions and upstanding features capped by erosional remnants of Tawil sandstone extend across the main outcrop belt of the Tayyarat formation. Where it is exposed in windows in the Tawil formation, the Tayyarat formation correlates with large dark patches visible on aerial photographs and Landsat imagery. The dark surface of the formation in the windows is a gravel formed by fragments of Scolithus sp. tubes eroded from the top of the formation and 
blackened by weathering. Where it is projected into the subsurface of Wadi as Sirhan in the northeastern corner of the quadrangle (cross section A-A', plate 1), the Tayyarat formation is believed to be Early Silurian (Llandoverian) in age and is composed of marine shale and siltstone. This interpretation is based on data obtained from a deep drill hole (Aramco S-460) located a few kilometers to the north of the quadrangle (Meissner and others, 1989). Trace fossils of Scolithus sp. found in the Tayyarat in the southwestern part of the quadrangle attest to a marine near-shore environment, whereas the more shaly lithology of the formation in the subsurface to the northeast may attest to a deeper water marine facies.

The contact with the overlying Tawil formation is unconformable and marks an hiatus in the geologic record extending from the Early Silurian to the Early Devonian.

\section{Tawil Formation}

The Early Devonian Tawil Formation (Dt) crops out in large areas of the quadrangle (plate 1); the largest area extends from the southern border to the Thaniyat escarpment in the north and At Tubayq in the northwest. The formation also crops out in an east-trending belt along the rim of the Sirhan-Turayf basin north of $\mathrm{Al}$ 'Urayq in the eastern half of the quadrangle. The presence of a thin shaly facies of the Tawil formation is suggested in the subsurface of Wadi as Sirhan (cross section A-A', plate 1), but this has not been confirmed.

The Tawil Formation is equivalent to the "Tawil Member" of the Tabuk Formation of Powers and others (1966), and Powers (1968). At the 23rd meeting of the DGMR Stratigraphic Committee, D. Vaslet of the Bureau de Recherches Geologiques et Minieres (BRGM) proposed to revise the nomenclature for the Tabuk Formation of Powers (1968). The term "Tabuk Formation" was discarded and the "Tawil Member" was changed to "Tawil Formation." For the purposes of this report, the type section of the Tawil Member in the escarpment of At Tawil (lat $29^{\circ} 29^{\prime}$ N., long $39^{\circ} 30^{\prime}$ E.) is retained for the Tawil Formation.

The Tawil Formation consists of tan to light-gray sandstone that weathers dark reddish brown to black. The thickness of the formation cannot be determined in the map area, but to the east of the quadrangle, at At Tawil, it is about $200 \mathrm{~m}$ thick. The sandstone is mostly medium to coarse grained and contains layers of very coarse to grit-size quartz grains and scattered pebbles. It is poorly sorted, although fine-to-medium grained, well-sorted beds occur locally. The sandstone is medium to thick bedded and massive, and contains abundant straight, high-angle cross beds. Ironstone layers and concretions are common, and iron oxide completely replaces the ironstone locally. This replacement is evident on the flat mountain tops of Umm Juthjath, in the east-central part of the quadrangle, where fragments of goethite cover the surface. However, these iron-oxide fragments are not present in sufficent quantity to be of economic value. 
The broad plain of Mughayra underlain by rocks of the Tawil Formation in the western part of the quadrangle is crossed by long sandstone ridges that appear as lineaments on the geologic map. These ridges have a N. $25^{\circ}-40^{\circ} \mathrm{W}$. orientation and are as much as $20 \mathrm{~km}$ long and $30 \mathrm{~m}$ high. Their origin is uncertain, but they are thought to be part of a macrojoint system related to the rifting of the Red Sea. In most cases, beds within the ridges dip $3^{\circ}-10^{\circ} \mathrm{W}$., and in extreme cases are vertical or overturned. The eastern sides of the ridges form a gentle scarp. The regional dip of the Tawil Formation is slightly east-northeast.

The presence of Scolithus-like trace fossils in 20-to-80-cm thick intervals of siltstone and fine-grained sandstone in the Tawil Formation suggests near-shore marine conditions of deposition, an interpretation that is consistent with Powers' (1968) statement that abundant pelecypod casts and molds occur in the formation. On the other hand, Lozej $(1983,1984)$ believes that much of the Tawil Formation was deposited in a fluvial-deltaic environment. Apparently there were periods of shoreline fluctuation due to episodes of marine transgression and regression during deposition of the Tawil Formation.

In the south-central part of the quadrangle, including the Wadi Fajr (south) area, the Tawil Formation is in conformable contact with the overlying Early Devonian Jauf Formation. However, at the Thaniyat escarpment and a few other places along the rim of the basin, the Tawil Formation is in unconformable contact with the overlying Zallum member of the Cretaceous Aruma Formation; where the Zallum is absent, the Tawil Formation is in unconformable contact with rocks of the Tertiary Turayf group. North of Umm Juthjath, in the east-central part of the map area, the Tawil is directly overlain by a thick deposit of Quaternary duricrust.

\section{JAUf Formation}

The type locality of the Jauf Formation is a composite of 10 isolated sections within a 30-km radius north and northwest of the town of Al Jawf (Powers, 1968), in the Al Jawf quadrangle east of the map area. The Jauf Formation at the type locality is described as Devonian (probably Early and Middle) in age. The formation at the type locality is about $300 \mathrm{~m}$ thick and consists of varicolored silty shale with several thin beds of limestone and dolomite in the upper part and near the base; there are also thin beds of sandstone at several levels. Most of the formation is of marine origin.

The Jauf Formation in the Thaniyat Turayf quadrangle consists of a lower and upper member, but because of poor boundary exposures the two members are compiled as a single map unit $(\mathrm{Dj})$. The formation conformably overlies the Devonian Tawil Formation, and in the southern part of the map area it is conformably overlain by the Devonian $\mathrm{Al} \mathrm{Jubah} \mathrm{formation.} \mathrm{In} \mathrm{the} \mathrm{central} \mathrm{part} \mathrm{of} \mathrm{the}$ map area, the Al Jubah formation is missing and the Jauf Formation is directly 
overlain by Cretaceous to Tertiary rocks of the Aruma and Jalamid formations. In this area, the Jawf Formation is truncated by a major pre-Late Cretaceous unconformity and is thinner than elsewhere (fig. 4). At one site about $2 \mathrm{~km}$ west of Wadi Umm Nukaylah, the Jauf dips $28^{\circ} \mathrm{S}$. in angular discordance with the overlying Zallum member of the Cretaceous Aruma Formation. However, such steep angular discordance at the Jauf-Aruma contact is an isolated feature not seen elsewhere.

\section{Lower Member}

The Lower member of the Jauf Formation in the Thaniyat Turayf quadrangle (Djl, fig. 2) is correlated with a Jauf section measured by Bigot (1970) at Al Jiraniyat near the southern border of the quadrangle. At Al Jiraniyat, the Lower member is about $145 \mathrm{~m}$ thick and consists of sandstone, limestone, and silty gypsiferous shale (fig. 3). In the Al Jiraniyat and $\mathrm{Al}$ Hawi areas, the basal part of the Lower member is composed of about $60 \mathrm{~m}$ of semifriable sandstone that is locally bright red to purple, grading into shades of yellow and brown. This unit contains long, low-sweeping cross-beds and rounded and frosted quartz grains that are comparable to those of modern sand dunes, indicating an eolian influence during its deposition. North of the Al Hawi area, the basal sandstone loses its reddish color and becomes thin bedded, forming gentle slopes in sharp contact with the resistant rocks of the underlying Tawil Formation. The remainder of the Lower member consists mostly of shale, sandstone, and thin limestone interbeds. The sandstone is light brown to gray, poorly sorted, and thin bedded. It is calcareous and in many places the bedding surfaces show signs of bioturbation. The shale is green with red and yellow bands. It is silty, and contains large clear to translucent gypsum plates, as well as secondary gypsum veins that fill joints and fractures. The limestone is light gray, clastic and argillaceous, stratified, and forms benches in the nonresistant sandstone and shale.

\section{Upper Member}

The Upper member of the Jauf Formation (Dju, fig. 3) is about $70 \mathrm{~m}$ thick and similar in composition to the upper part of the Lower member, except that it contains more fossiliferous limestone beds. The member is composed of green and yellow shale that alternates with light yellowish-brown friable sandstone and gray to buff, thin-bedded, compact limestone. The limestone includes algal, biohermal, and stromatolitic intervals, as well as fossiliferous layers that contain pelecypod and brachiopod fossils. The limestone beds form the rim rock of buttes and mesas that occur in the southern part of the outcrop area of the Jauf Formation.

One of the flat-topped buttes capped by limestone has a surficial deposit of wind-worn ventifacts; these usually have three curved faces intersecting in sharp edges (dreikanter), a desert phenomena resulting from the abrasion of thin fragments of limestone by wind-blown sand. 


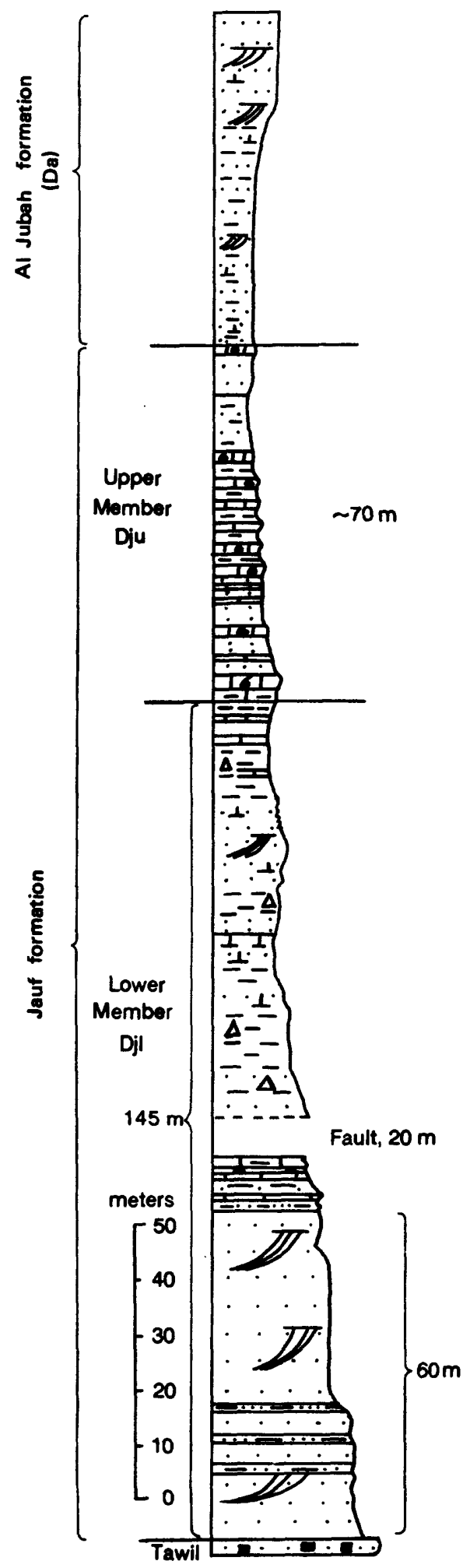

Sandstone, light gray, weathers reddish brown; fine to medium grained, subangular; thin to thick beds, cross bedded, calcareous. Upper part resistant.

Silty shale interbeds, green and yellow, calcareous.

Shale, green and yellow, and sandstone, yellowish brown, friable. Limestone, buff to gray, compact, thin bedded. Algal, biohermal, and stromatolitic layers, with fossil brachiopods and pelecypods.

Shale, green with red and yellow bands, silty, gypsiferous. Sandstone, light brown to gray, poorly sorted, thin bedded and calcareous, bioturbated. Limestone, light gray, partly clastic and argillaceous.

Sandstone, bright red to purple, grading to yellow and brown; frosted, rounded quartz grains (eolian); long. Low-angle cross beds; some siltstone layers.

Figure 3.--Measured section of the Jauf and Al Jabah formations (Al Jiraniyat), Thaniyat Turayf quadrangle. Adapted from Bigot (1970). (See figure 2 for explanation of lithologic symbols.) 


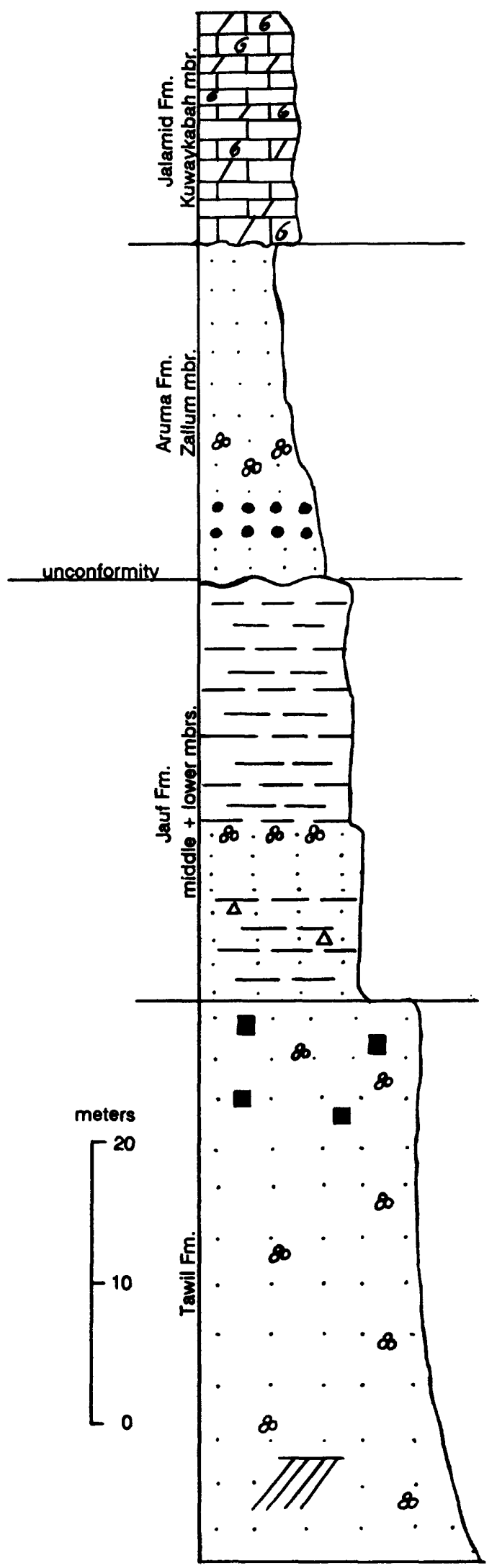

Dolomitic limestone, buff to pale yellow, bioclastic, containing bivalve molds and gastropod casts.

Sandstone, yellow.

Sandstone, purple, dark yellow, red, and varicolored; friable.

Conglomeratic sandstone.

Cobble conglomerate; pebbles and cobbles of quartzite.

Sandstone, yellow, fine grained; friable.

Shale, red, brown, and green; fissile.

Sandstone, fine to medium grained with quartz pebbles; claystone, pink to red.

Sandstone, brown to dark brown; sandstone concretions $1-2 \mathrm{~cm}$ diameter; secondary calcite filling fractures; fragments of ironstone near top.

Sandstone, yellow, light to dark brown, coarse to medium grained, cross bedded.

Figure 4.--Measured section (DF9) of the Tawil, Jauf, Aruma, and Jalamid formations at the Ja'alat as Sawda escarpment, Thaniyat Turayf quadrangle. (See figure 2 for explanation of lithologic symbols.) 


\section{Al Jubah Formation}

The $\mathrm{Al}$ Jubah formation (Da), named for $\mathrm{Al}$ Jubah in the northeastern part of the Al Jauf quadrangle to the east of the map area, is a new formation proposed by Meissner and others (1989). It consists of dark-weathering Devonian sandstone, silty shale, and siltstone that, in the type area, conformably overlies the Jauf Formation and is unconformably overlain by the Aruma Formation. The Al Jubah formation is at least $220 \mathrm{~m}$ thick and contains Prototaxites sp., a tree-like fungus that lived only during the Devonian period.

The rocks of the Al Jubah formation that crop out in the map area, as well as those found at the type locality, were mapped by Bramkamp and others (1963) as the Sakaka sandstone. The Al Jubah was believed to range in age from post-Devonian to pre-Cretaceous. In the map area, the Al Jubah formation is confined to the south-central part of the quadrangle, where it caps several isolated buttes. In these limited outcrops, the formation is as much as $60 \mathrm{~m}$ thick. It consists of interbedded light-gray sandstone and green and yellow silty shale that weather reddish brown and are locally marked by a black coating. The sandstone is fine to medium grained, subangular, and thin to thick bedded; the sandstone and shale are calcareous.

No fossilized Prototaxites sp. were found in the Al Jubah formation of the map area. However, spines and other fragments of what appear to be Devonian fish fossil remains similar to those identified in the Al Jubah formation of the Al Jawf quandrangle (H.A. McClure, Aramco, written communication) are present.

\section{Aruma Formation}

\section{Zallum Member and Undifferentiated Cretaceous Rocks}

The Zallum member (Zallum sandstone of Powers, 1968) is the only one of three members of the Aruma Formation defined by van Eck (1985) that occurs in the map area. It is named from outcrops at Khashm Zallum (lat $30^{\circ} 18^{\prime} \mathrm{N}$., long $40^{\circ} 21^{\prime}$ E.), located northeast of the quadrangle. In the Thaniyat Turayf quadrangle, the Zallum member (Kaz) has been mapped along the Thaniyat escarpment west as far as the locality where it pinches out. It also occurs discontinuously along the Ja'alat ash Shahba and Ja'alat as Sawda escarpments to the southeast as far as Umm Nukhaylah in the east-central part of the quadrangle. It ranges in thickness from about 10 to $60 \mathrm{~m}$ and consists mostly of white to mottled brownish red, lavender, and purple unconsolidated sandstone. In many places, the member has a quartzite bed near its top, and at Ja'alat as Sawda has a unique, approximately 2-m-thick cobble conglomerate near its base (fig. 4). The conglomerate bed consists of small rounded quartzite cobbles in a coarse pebbly sandstone matrix, indicating local high-energy deposition at the Jauf-Zallum unconformity. 
No fossils were found in the Zallum member within the quadrangle, but the Late Cretaceous (Maastrichtian) foraminifera Loftusia sp. has been identified in a carbonate facies of the Zallum near Ar'Ar, northeast of the quadrangle (van Eck, 1985; Bayliss, 1983).

Undifferentiated Cretaceous rocks $(\mathrm{Ku})$ projected in the subsurface in the northeastern part of the quadrangle (cross section A-A', pl. 1) are estimated to be more than $20 \mathrm{~m}$ thick and consist of sandy limestone. They are interpreted to be a lateral facies of the Zallum member.

The contact of the Zallum member with the overlying Late CretaceousPaleocene Thaniyat Phosphorite member of the Jalamid formation appears gradational, especially in the Thaniyat escarpment. Along the Thaniyat escarpment, the upper 1.5 to $3 \mathrm{~m}$ of the sandstone of the Zallum member contains phosphate grains as high in the section as the base of the Thaniyat Phosphorite member. To the southeast, at Ja'alat ash Shahba and Ja'alat as Sawda, the Thaniyat Phosphorite member is absent and the Zallum is directly overlain by the carbonate Kuwaykabah member of the Jalamid formation. However, both the Zallum and Kuwaykabah members are locally phosphatic at the Aruma-Jalamid contact.

\section{TuraYf Group}

The Turayf group is an informal designation used in mapping the sedimentary phosphatic-carbonate succession of the Sirhan-Turayf basin. Overall, the rocks of the group range in age from Late Cretaceous (Maastrichtian) to Middle Eocene (Lutetian) (Riddler and others, 1984), and are subdivided into three formations: the Jalamid, the Mira, and the Umm Wu'al, in ascending stratigraphic order. The Umm Wu'al formation is not present in the Thaniyat Turayf quadrangle. These formations represent three cycles of carbonate sedimentation that comprised brief, repetitive, onlapping transgressive-regressive events on shallow marine shelves; they are distinguished by phosphorite members at the base of each cycle. An inner-shelf subtidal to restricted-shelf depositional environment is generally indicated (Riddler and others, 1986). The following detailed descriptions are by Griffin and others (1984) and Smith (1983).

\section{Jalamid Formation}

The Jalamid formation takes its name from outcrops in the northeast part of the Sirhan-Turayf basin near the Al Jalamid Trans-Arabian Pipeline pump station (175 km northeast of map area). The Jalamid is exposed in the north-western part of the quadrangle and in the Ja'alat ash Shahba and Ja'alat as Sawda areas. These outcrops are in the Southwestern Area that extends into the Wadi As Sirhan quadrangle (Meissner and others, 1989). The name "Southwestern Area" was first used by Riofinex; it continued in use in subsequent literature; it includes the 
phosphate-bearing rocks of the southwestern part of the Sirhan-Turayf basin (fig. 1). (Note that although the map unit designation ( $\mathrm{Tt}$ ) for the Jalamid formation and its associated members indicates wholly Tertiary ages for the formation, it does, in fact, extend partly into the Late Cretaceous.

The Jalamid formation is subdivided into two members: the Thaniyat Phosphorite and the Kuwaykabah. The Kuwaykabah member is, in turn, subdivided into two beds: the Qutayfah and the Ghuzay.

Thaniyat Phosphorite member--The Thaniyat Phosphorite member (Ttjt) takes its name from exposures in the Thaniyat escarpment that forms the southern edge of the Southwestern Area. Along the eastern part of the escarpment, the member is 3 to $7 \mathrm{~m}$ thick and consists of interbedded phosphorite, chert, shale, micrite, and dolomicrite. The type section of the member in the eastern escarpment is located at an adit (lat $29^{\circ} 42^{\prime} \mathrm{N}$., long $37^{\circ} 53^{\prime}$ E.; "USGS Adit (WG 104)" on plate 1) excavated for bulk samples by the USGS (Meissner and Ankary, 1972b) and described by Griffin and others (1984; their section WG 104) (figs. 5 and 6).

The total thickness of the member at the type section is about $3.5 \mathrm{~m}$. At the base is a bed of phosphorite $(1.70 \mathrm{~m}$ thick) that is mostly friable to semifriable, although it contains a 10-cm micrite parting near its top. This basal bed accounts for most of the phosphorite resources estimated for the Thaniyat Phosphorite member in the Thaniyat area by Meissner and Ankary (1972b), and Petromin-Graenges (unpub. data). The upper part of the type section is composed of thin beds of phosphorite (semifriable to calcareous and hard), chert, micrite, and dolomicrite. The aggregate thickness of the phosphorite beds in the upper part of the section is $0.50 \mathrm{~m}$.

In the western part of the Thaniyat escarpment, the Thaniyat Phosphorite member thickens to more than $25 \mathrm{~m}$, but the phosphorite beds remain thin, partly silicified, and are interbedded with limestone, shale, and chert. Phosphatic quartz sandstone and sandy carbonate-cemented phosphorite are common at the base of the member.

The Thaniyat Phosphorite member has not been mapped east of Thaniyat ar Rilan. However, in the Ja'alat ash Shahba and Ja'alat as Sawda escarpments, a thin lenticular zone at the base of the Kuwaykabah member contains sandy phosphatic carbonate rocks, and in places, a $10-25-\mathrm{cm}$ bed of phosphorite that may be equivalent to the Thaniyat Phosphorite member.

The member dips northeastward into the subsurface and is penetrated at a depth of about $133 \mathrm{~m}$ in drill hole P48, located at the eastern border of the Southwestern Area where it is composed of chert, micrite, and sandstone containing friable calcareous phosphate pellets (Ryder and Kluyver, 1983). 


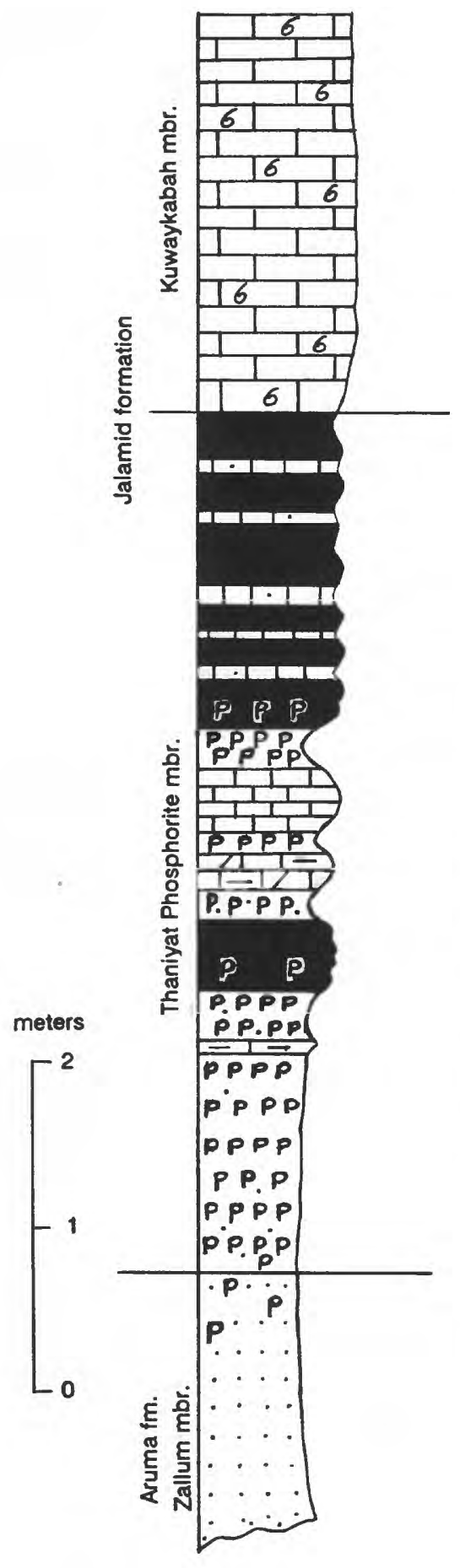

Bioclastic limestone, buff gray; 3-5 $\mathrm{mm}$ fossil-shell fragments.

Chert, dark brown, beds and lenses; highly contorted; micrite interbeds; silty.

Phosphatic chert, dark brown.

Phosphorite, white to puff; calcareous to semifriable.

Micrite, white to buff; silty, porous.

Phosphorite, white to buff; calcareous to semifriable.

Dolomicrite, silty, shaly; local fissility.

Phosphorite, white calcareous to semifriable, bioclastic.

Chert, dark brown, base slightly phosphatic.

Phosphorite, white, calcareous to semifriable, slightly sandy; bioclastic. Micrite, dark brown, shaly.

Phosphorite, white to buff, semifriable to friable; abundant bioclastic debris, shark's teeth, slightly sandy.

Sandstone, white to buff, unconsolidated; locally pure white quartz sand; locally phosphatic.

Figure 5.--Measured section at site of USGS adit (WG 104), Thaniyat escarpment, Thaniyat Turayf quadrangle. (See figure 2 for explanation of lithologic symbols.) 


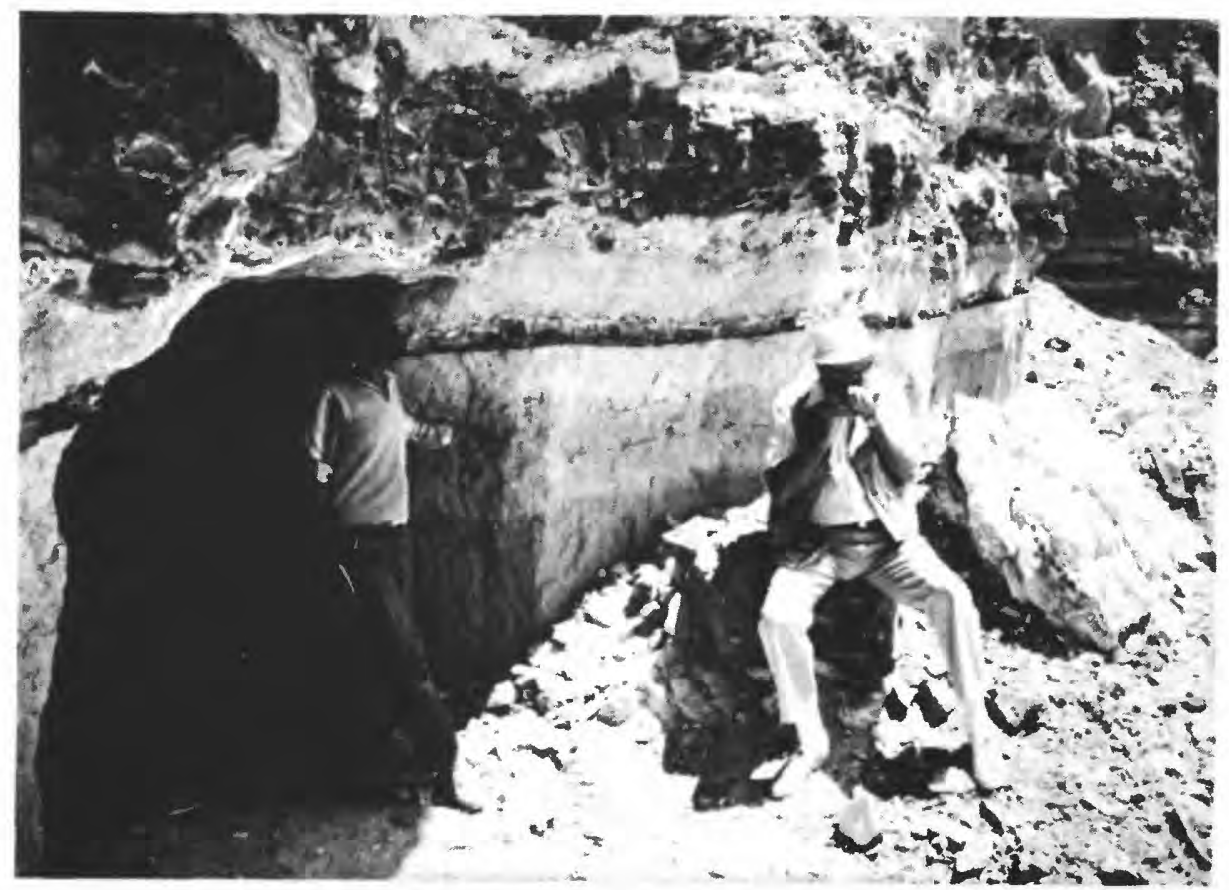

Figure 6.--Close-up view of the USGS adit (WG 104) in basal phosphorite bed of the Thaniyat Phosphorite member.

On the basis of microfossils and fish teeth found in the Thaniyat area (Bayliss, 1983; Capetta and Riddler, 1985), the age of the Thaniyat Phosphorite member is Late Cretaceous (Maastrichtian) to Early Paleocene. Contact with the overlying Kuwaykabah member is conformable.

Kuwaykabah member--This member (Ttjk) and its subdivisions take their names from prominent wadis in the Southwestern Area in the vicinity of the type sections. The lower (Qutayfah) bed of the Kuwaykabah member is 30 to 40 m thick. It consists of generally well-bedded, white or buff to pink, partially recrystallized micritic limestone and partly shaly, leached micritic limestone containing grayish-brown chert nodules and lenses. Some thin bioclastic interbeds containing bivalve and gastropod shell fragments are present. The basal limestone is slightly porous and silty, whereas secondary calcite is common toward the top of the bed. Its age is presumed to be Early Paleocene.

The upper bed of the Kuwaykabah member, the Ghuzay, is 15 to $40 \mathrm{~m}$ thick. It consists of buff to brown bioclastic limestone that contains bivalve and gastropod fragments. Coarse calcite replaces some shells and occurs in vugs and veins. 
Much of the dissected hilly terrain in the western half of the Southwestern Area is underlain by the Kuwaykabah member; it also forms the rim rock of the Thaniyat escarpment, Jabal Wailah, Ja'alat ash Shahba, and Ja'alat as Sawda as far as a point to the west of Umm Nukhaylah. It is composed of a highly leached interbedded sequence of bioclastic and nonbioclastic, partly dolomitic limestone. At Ja'alat ash Shahba and Ja'alat as Sawda, this unit is 15 to $20 \mathrm{~m}$ thick, buff colored, sandy, and phosphatic, especially at the base. The top of the member contains chert nodules $2 \mathrm{~cm}$ to $2 \mathrm{~m}$ in diameter. Circular depressions formed in the host rock where the chert nodules were eroded away. Large gastropod and bivalve casts and molds (10 to $15 \mathrm{~cm}$ in diameter) occur at several intervals. West of Umm Nukhaylah, the limestone is argillaceous and contains geodes $10-35 \mathrm{~cm}$ in diameter.

The contact of the Jalamid formation with the overlying Ghinah Phosphorite member of the Mira formation is disconformable.

\section{Mira Formation}

The Mira formation takes its name from Wadi al Mira in the northeastern part of the Sirhan-Turayf basin (fig. 1). It is exposed in the northwestern part of the quadrangle where stratigraphic studies indicate that it is composed of four members: the Ghinah Phosphorite, the Hawsa, the Mindassah, and the Sib, in ascending stratigraphic order. However, for the purposes of geologic compilation, only the basal phosphorite member and an undivided unit that comprises the three upper members are shown on plate 1 .

Ghinah Phosphorite member--This unit (Ttmg) ranges in thickness from 0 to $15 \mathrm{~m}$ and crops out on the flanks of hills in the western half of the Southwestern Area, as well as in the hills on both sides of the pass of Thaniyat Turayf. The type sections are located in Wadi al Kuwaykabah (lat $29^{\circ} 54^{\prime}$ N., long $37^{\circ} 36^{\prime}$ E.) and at Jabal al Hawsa (lat $29^{\circ} 43^{\prime} \mathrm{N}$., long $37^{\circ} 50^{\prime} \mathrm{E}$.). The member consists of an interbedded sequence of as many as four thin $(10-30 \mathrm{~cm})$ phosphorite beds and slightly phosphatic micritic limestone, claystone, fissile shale, and chert. The phosphorite is semifriable to hard, carbonate-cemented, and contains fecal pellets, bioclastic debris, and fossil sharks' teeth. The uppermost phosphorite bed is commonly conglomeratic with poorly sorted phosphate pellets, quartz grains, and chert pebbles. The top of the member consists of buff to yellow highly fissile shale that grades upward into greenish-gray claystone. The shale and claystone are phosphatic and contain small geodes.

Age determinations on diagnostic dynophyte cysts extracted from shale in the Ghinah Phosphorite indicate a Late Paleocene to Early Eocene age for the member. The contact with the overlying Hawsa member is conformable.

Hawsa, Mindassah, and Sib members, undivided--This map unit (Ttm) is a combination of the three upper members of the Mira formation. The lowermost of 
the three, the Hawsa member, occurs in the dissected hilly terrain from the central part of the Southwestern Area to the Al Busayta fault. The type locality described for the Hawsa member occurs at Jabal al Hawsa, north of the Thaniyat escarpment. The member is $30-70 \mathrm{~m}$ thick and consists of generally well-bedded limestone and claystone interbedded with chert, shale, and bioclastic limestone. Its base is composed of slightly phosphatic geode-bearing claystone that is overlain by a thin interval of siliceous and carbonate-cemented phosphorite and gray chert. Above the base is buff to yellow, highly fissile shale and leached, powdery micritic limestone. The upper part of the member consists of geode-bearing micritic limestone and bedded and nodular chert. In the upper part of the Hawsa member, there is a bed of siliceous geodes characterized by unique turtleback-like exterior shells that have a mud-cracked appearance. The exterior cracks are filled with quartz that apparently precipitated from silica-rich solutions that escaped from the interior of the geode during its formation. These geodes were first noted by Meissner and Ankary (1971), and examined and described in detail by Matzko and Naqvi (1982). Limestone in the upper part of the Hawsa member contains fossilized nummulites, gastropods, and bivalves. Among these, Early Eocene Nummulites planulatus have been identified in the Southwestern Area near Thaniyat Turayf (Bayliss, 1983). The contact with the overlying Mindassah member is transitional.

The Mindassah member is exposed in the southeastern Southwestern Area, where it caps the hills of a complexly dissected plateau. The Mindassah type localities are located in Wadi umm Arta and Busayta al Mindassah (lat $29^{\circ} 47^{\prime} \mathrm{N}$., long $37^{\circ} 59^{\prime} \mathrm{E}$. and lat $29^{\circ} 47^{\prime} \mathrm{N}$., long $37^{\circ} 57^{\prime}$ E., respectively). The members' thickness is about $25 \mathrm{~m}$; it consists of buff-colored bioclastic limestone containing many Nummulites sp., bivalve, and gastropod fossils, and layers of coquina. The age of the nummulites is Early Eocene (Bayliss, 1982). The members' matrix is partially leached to recrystallized, hard micritic limestone. The Mindassah weathers into very coarse, rough outcrops and is in conformable contact with the overlying Sib member.

The Sib member, the uppermost unit of the Turayf group exposed in the quadrangle, is named for Khabra as Sib northeast of the map area (type localities are lat $30^{\circ} 31^{\prime}$ N., long $39^{\circ} 10^{\prime}$ E.; lat $30^{\circ} 22^{\prime}$ N., long $39^{\circ} 10^{\prime}$ E.; and lat $30^{\circ} 12^{\prime}$ N., long $39^{\circ} 39^{\prime}$ E.). The member is exposed in the northeastern corner of the Southwestern Area and in isolated areas northeast of the Ja'alat ash Shahba and Ja'alat as Sawda escarpments. It is represented by siliceous float capping gently undulating hills. However, outcrops in wadi banks reveal that the member consists of beds of pale-gray silicified limestone $20-50 \mathrm{~cm}$ thick composed of calcite, chert breccia, and recrystallized, sparry, nonsilicified micrite interbedded with chert. The Sib also contains calcareous nummulitic-limestone intervals and thin phosphatic beds that may cover large areas due to the gently undulating terrain. Phosphatic chert is common and some calcareous phosphorite is present. Outcrop and drill-hole data indicate that, in the Southwestern Area, the Sib is $80 \mathrm{~m}$ thick maximum. 
Northeast of Ja'alat ash Shahba and Ja'alat as Sawda, the Sib is exposed in isolated areas surrounded by duricrust. It is about $20 \mathrm{~m}$ thick and consists of interbedded white to cream-colored micritic limestone, brown and gray chert, and sparry limestone. In these areas, the Sib member was formerly mapped as Mindassah and most of the area from the central part of the quadrangle to its eastern border, now designated duricrust (Qdc), was part of the Sib member. These modifications were prompted by recent completion of more detailed mapping.

The extent of silicification and calcification within the Sib member suggests that it represents a major erosional episode during a marine regression; minor transgressions within this episode are represented by thin phosphatic intervals. Early Eocene Nummulites planulatus have been identified in the Sib by Bayliss (1983).

\section{Turayf Group, Undivided}

A unit of Turayf group undivided $(\mathrm{Tt})$ is projected from Aramco drill hole $\mathrm{S}-460$ into the northeastern part of the quadrangle (cross section $\mathrm{A}-\mathrm{A}^{\prime}$, plate 1 ). The unit is about $560 \mathrm{~m}$ thick and is composed of limestone, chert, and very small amounts of marl, shale, and sandy limestone. Eocene and Paleocene rocks were identified (Aramco, unpublished data) in the drill hole and the drillcore includes phosphatic limestone and a few thin layers of phosphate. Foraminifera found in the drillcore, including Valvulineria sp., Virgulina sp., Hopkinsina sp., and Globorotalia sp., attest to the marine origin of the Eocene and Paleocene rocks.

\section{Sirhan Formation}

Although a lack of diagnostic fossils prevent a reliable age designation at this time, most of the youngest Tertiary sedimentary rocks in the Thaniyat Turayf quadrangle are believed to be Miocene in age, and some Pliocene. These rocks are informally named the Sirhan formation (Tsu) for exposures in the Wadi As Sirhan depression, which extends across the northeastern corner of the map area. The Sirhan outcrops are very poorly exposed, highly weathered, and in many places partly covered by Quaternary deposits, making it difficult to determine the limits of the formation. There are no continuous exposures of the Sirhan formation, but rather a number of small scattered outcrops that exhibit little surface expression. Where sufficiently dense, these exposures have been compiled on the map sheet as continuous units rather than as individual outcrops.

The Sirhan formation is composed of sandstone and limestone interbeds. The sandstone is white to light brown, poorly sorted, fine to very coarse grained, friable and loose, calcareous, and poorly bedded in most places. However, the sandstone is locally mottled light and dark gray, and is very thin bedded, but remains poorly sorted and calcareous. Where strongly weathered, the sandstone exposures are 
marked by a conspicuous, thin ferruginous cap rock characterized by an irregular texture. This cap rock is limonitic and mottled rusty brown and gray. Locally, it contains a few spots of greenish sandstone that appear to be stained by copper. Limestone interbedded with the sandstone of the Sirhan formation is white to light gray, sandy, amorphous to microcrystalline, and thin bedded. It is locally argillaceous and chalky, and weathering produces narrow light and dark layers that give it a streaked appearance. In one area, the limestone is dark gray and brown, microcrystalline, vuggy, and platy. The dark color of some limestone may be due to less extensive weathering.

Outcrops generally expose a sequence less than $2 \mathrm{~m}$ thick in the desert plain, and nowhere can the complete thickness of the Sirhan formation be measured at the surface. However, $131 \mathrm{~m}$ of the formation was penetrated in Aramco drill hole S-460. In this hole, the Sirhan formation consists of sandstone, limestone, and marl; the upper part is composed of calcareous sandstone, the middle part is interbedded sandstone and partly sandy and marly limestone, and the lower part is claystone or marl. It is not known if this subdivision is regional, but examination of the drillcore suggests that the interbedded sandstone and limestone exposed at the surface in the map area is part of the middle subdivision of the Sirhan formation. The maximum estimated thickness of the formation projected into the quadrangle is $80 \mathrm{~m}$ (cross section A-A', pl. 1).

\section{SEDIMENTARY HISTORY OF THE PREQUATERNARY ROCKS}

The Sarah formation of Late Ordovician-Early Silurian age consists predominantly of poorly sorted sandstone marked by considerable variation in the angularity of the consituent quartz grains, which suggests a littoral environment (intertidal) of deposition. However, for part of the formation, the occurrence of Cruziana sp. trace fossils indicates a neritic environment (between low tide and the edge of the continental shelf). Marine conditions continued during the deposition of the Early Silurian Tayyarat formation. This formation contains Scolithus-like trace fossils that indicate an intertidal environment, and a shaly facies in Wadi as Sirhan that suggests offshore, deep water marine conditions.

There is a long depositional hiatus between the Early Silurian Tayyarat formation and the Early Devonian Tawil Formation. The Tawil Formation contains Scolithus sp. trace fossils and casts and molds of pelecypods, indicating intertidal, near-shore conditions. These marine conditions alternated with fluvial-deltaic environments that were caused by periodic marine regressions (indicated by the presence of braided-stream, channel-fill, and delta-plain sedimentary features). 
Alternating marine and continental environments also prevailed during the deposition of the Early Devonian Jauf Formation. In the map area, the lower member of the Jauf Formation has a basal sandstone unit that contains rounded and partly frosted grains, indicating an eolian environment; this environment was succeeded by brackish-water conditions, indicated by the presence of bioturbated sandstone and gypsiferous shale containing a few beds of clastic argillaceous limestone. The upper member of the Jauf Formation is composed of shale and sandstone, and has interbeds of fossiliferous limestone containing algal, biohermal, and stromatolitic intervals, as well as layers containing fossilized pelecypods and brachiopods, which are features indicative of a shallow-water marine environment.

The Early Devonian Al Jubah formation is mostly sandstone of continental (probably fluvial deltaic) origin. No fossils were found in this formation within the Thaniyat Turayf quadrangle, but to the east, in the Al Jawf quadrangle, the formation contains fossil remains of Prototaxites sp., a giant tree-like fungus believed to have grown on land near rivers and deltas (Francis M. Hueber, Smithsonian Institution, Washington, D.C., verbal communication, 1987).

Another hiatus in the sedimentary history of the region occurred between the Early Devonian Al Jubah formation and the Late Cretaceous Zallum member of the Aruma Formation, during which time Gondwanaland broke up, and what is now the Arabian Peninsula moved northward. A carbonate facies of the Zallum member that is present northeast of the map area contains Loftusia sp., a shallow-water marine foraminifera. A cobble-conglomerate bed near the base of the Zallum attests to high-energy deposition above the Devonian-Cretaceous unconformity. The sandstone of the Zallum member is probably of marine-strand origin.

At the time of deposition of the Late Cretaceous-Tertiary (Paleocene to Middle Eocene) carbonate sequence of the Turayf group, the Tethys Sea, ancestor of the Mediterranean, occupied a wide, shallow-marine shelf in what is now the Sirhan-Turayf basin. The Jalamid and Mira formations of the Turayf group in the Thaniyat Turayf quadrangle represent two periods of cyclic carbonate sedimentation marked by brief, repetitive onlapping transgressive-regressive events. An inner-shelf subtidal to restricted-shelf depositional environment is generally indicated for the Turayf. Silicification and calcification at the top of the Sib member suggests that a major erosional event occurred during a marine regression.

After the Middle Eocene, there is an hiatus in the sedimentary record that extends to the Sirhan formation (Miocene, and possibly Pliocene age). The Sirhan formation consists mainly of poorly sorted nonfossiliferous continental sandstone that contains fine to pebble-sized quartz grains. The bulk of the sandstone may have been deposited as alluvial fans on the flanks of the Wadi as Sirhan graben complex. At one locality north of the map area, sandy, chalky limestone interbedded with the sandstone contains echinoid fossils, which indicates a marine environment. The Sirhan formation was deposited in a continental environment that occasionally was subjected to marine incursions. 


\section{QUATERNARY DEPOSITS}

\section{DURICRUST}

Extensive deposits of calcareous and gypsiferous duricrust (Qdc) occur in the Thaniyat Turayf quadrangle, south and east of the Al Busayta plain. The origin of duricrust is not clearly understood, but it is apparently associated with periods of wetter climate when hard calcareous and gypsiferous material was precipitated at and near the surface by evaporating groundwater. The evaporative minerals were subsequently leached from the underlying bedrock, and the process of capillary action, as well as dissolution and recrystallization of minerals with different specific volumes, broke the bedrock into numerous fragments and blocks that later become a part of the crust. Good examples of broken bedrock in duricrust are present south and east of the Al Busayta plain, where unbedded, sharp, chaotically mixed pieces of chert and siliceous limestone appear to have come from underlying rocks of the Turayf group. Duricrust is consolidated and resistant, and forms banks and scarps as much as $30 \mathrm{~m}$ high that completely masks bedrock. This crust was mapped as the Hibr formation by Bramkamp and others (1963), and as the Sib member by Riddler and others (1986).

In the eastern part of the $\mathrm{Al} \mathrm{Huj} \mathrm{area,} \mathrm{south} \mathrm{of} \mathrm{the} \mathrm{Al} \mathrm{'Urayq} \mathrm{sand} \mathrm{dunes,} \mathrm{a}$ mixed unit of gravel and duricrust $(\mathrm{Qg} / \mathrm{Qdc})$ forms sinuous deposits that are oriented in channels similar to streams. Bigot (1970, Appendix 1) mapped these deposits as Tertiary "conglomerate and white sandstone" and suggested that they were a bedded formation. The deposits are 3 to $4 \mathrm{~m}$ thick and consist of partially consolidated large cobble-sized pieces of limestone and siliceous boulders in a calcareous matrix of gravel and sandstone. However, there is no orientation or layering in the deposits that would suggest deposition by stream flow. Instead, the cobbles, boulders, gravel, and sand form a structureless mixture typical of residual duricrust. The reason for the channel-like orientation is not clear. A possible explanation is that the resistant crust preferentially formed over groundwater-rich wadis and thus preserved them from erosion. An "inverted wadi" resulted as less-resistant rocks adjacent to the wadi course were eroded faster than the wadi sediments, which were protected by a cap of consolidated duricrust. The topographical expression of the deposits is as a sinuous ridge. A good example of an inverted wadi occurs in the southeast corner of the Wadi as Sirhan quadrangle (north of the Thaniyat Turayf quadrangle), where a sinuous ridge $8.5 \mathrm{~m}$ long and $6 \mathrm{~m}$ high seemingly "flows" across the desert plain (Meissner and others, 1986).

The duricrust on either side of Wadi Fajr along the western side of Al Huj is more sheet-like and less coarse than the sinuous deposits described to the east. It masks large areas of the Jauf Formation as well as the Tawil Formation locally. The duricrust is partly calcareous and contains abundant secondary gypsum. In many places in the $\mathrm{Al} \mathrm{Huj}$ area, the duricrust is covered by a thin layer of gravel derived from the crust by weathering and disintegration. For this reason, it is indicated on 
the map with the symbol Qg/Qdc. Duricrust is known to have formed on rocks younger than Miocene and Pliocene, and is believed to be Quaternary in age.

\section{Unconsolidated Surface Deposits}

Unconsolidated surface deposits cover about 25 percent of the Thaniyat Turayf quadrangle. The plain of Al Busayta is completely covered by gravel that makes up the largest percentage of the surface deposits. Al Urayq, an arm of the An Nafud, occupies a large part of the quadrangle. Other smaller alluvial deposits are scattered throughout the map area.

\section{Gravel and Regolith Gravel}

The Al Busayta plain occupies much of the northeastern part of the Thaniyat Turayf quadrangle and extends northward into the Wadi as Sirhan quadrangle (Meissner and others, 1989). The surface gravels $(\mathrm{Qg})$ are mostly chert fragments 2-30 $\mathrm{cm}$ in length. In most places, the fragments are irregularly shaped, but locally occur as even-sided tabular pieces. Colors vary from yellow to brown and dark gray; mottled yellow and gray chert is often seen. Light-colored quartz pebbles are mixed in with the chert gravels. The pebbles are well rounded and are as long as $12 \mathrm{~cm}$. The quartz pebbles are most abundant in the north-central part of the plain. All of the gravel deposits of the Al Busayta plain are mixed with alluvial and eolian sand. Percussion drilling at Al Busayta penetrated gravel deposits more than $40 \mathrm{~m}$ thick (Ryder and Kluyver, 1983).

Wadis draining northward and eastward onto the Al Busayta plain contain gravel with composition and grain size similar to that of the plain. The Al Busayta gravel probably was deposited by periodic storm-generated flash flooding in these wadis. Gravel deposits are present in Wadi Fajr and smaller wadis of the quadrangle.

Regolith gravel (Qgr), consisting of a mixture of limestone, chert, and other rock fragments, forms sheets and trains that mask bedrock in the Wadi Umm Arta-Wadi Turayf area.

\section{Eolian Sand Deposits}

The Thaniyat Turayf quadrangle contains a variety of eolian sand deposits (Qes). Al Urayq is an arm of the An Nafud that protrudes northwestward into the southeastern corner of the map area. The An Nafud is the second largest dune desert in Saudi Arabia (after the Rub Al Khali); the bulk of its area lays to the southeast of the quadrangle. Al Urayq contains two types of sand terrain (Bramkamp and others, 1963): longitudinal and uruq. Longitudinal terrain comprises bush-and 
grass-covered sand and undulating sand sheets. The individual topographic forms are elongate parallel to the prevailing wind direction and are often partially stabilized by vegetation. Uruq sand terrain is composed of long, narrow, subparallel sand ridges and dune chains separated by broad sand valleys. Both landforms are visible on the Landsat base map of the quadrangle and have a prevailing northwest orientation, although barchan dunes near the north edge of Al Urayq are oriented transverse to the prevailing wind.

Many barchan dunes occur in the northeastern corner of the quadrangle and overlie either Quaternary gravel or rocks of the Sirhan formation. They are stable wave forms: present patterns are nearly identical to those seen on 10-year-old aerial photographs. The southwest end of Nafud al Ghuwaytah, a relatively small undulating sand body, is located on the east-central border of the map area. Patches of eolian sand are also present in the southern part of the Wadi Fajr area.

\section{Alluvial Deposits}

The map area contains large deposits of unconsolidated alluvial silt, sand, and gravel (Qu), mainly along wadi courses, but also in small depressions and basins. Finer grained deposits consisting of silt and clay (Qs) are found in undrained depressions (khabras) and form flat surfaces commonly devoid of vegetation. Local unconsolidated cobble-conglomerate deposits (not mapped separately) occur on tops of hills (the Jauf Formation) in the Al Hawi area, and on ridge tops (the Tawil Formation) in the Sidar Hills, located west of Wadi Fajr (south). The cobbles are composed of rounded chert and quartzite and are as much as $40 \mathrm{~cm}$ in diameter mixed with pebbles approximately $5 \mathrm{~cm}$ in diameter. They appear to be foreign to the underlying rock formations and indicate a high-energy environment of deposition. These cobble-conglomerate deposits are similar to the bedded-cobble conglomerate near the Zallum-Jauf formational contact at the Ja'alat as Sawda escarpment (fig. 4). This suggests that the resistant cobbles at $\mathrm{Al} \mathrm{Hawi}$ and Sidar are possibly erosional remnants of the Zallum member cobble bed.

\section{STRUCTURE}

The Phanerozoic sedimentary rocks in the Thaniyat Turayf quadrangle contain many faults, linear features, and macrojoints resulting from major tensional forces and subsidence produced by continental rifting associated with the formation of the Red Sea. The Wadi as Sirhan graben complex is the main structural feature in the map area (Regional Geologic Setting, plate 1) and occupies much of the eastern part of the quadrangle. Long northwest-trending sandstone ridges and faults are the dominant structural features of the western part of the quadrangle. 
In this report, we will put forward a new structural concept for the region: that the Al Busayta fault, the southwest boundary fault of the Wadi as Sirhan graben complex, does not die out near the central part of the quadrangle, but is offset to the west by a subsidiary fault along Thaniyat ar Rilan and continues to the southeast. The Al Busayta fault trends N. $26^{\circ} \mathrm{W}$. and is downthrown to the east. The throw of the Al Busayta fault decreases from about $100 \mathrm{~m}$ at the northern border of the quadrangle to about $25 \mathrm{~m}$ at Thaniyat ar Rilan near the central part of the map area. At Thaniyat ar Rilan, it is believed the Al Busayta fault shifts westward about $8 \mathrm{~km}$ along a lateral fault and discontinuously connects with the $\mathrm{Al} \mathrm{Huj}$ fault that trends southeast along the northeast side of the Al Huj plateau. This structural interpretation is of potential economic significance because it implies that the Wadi as Sirhan graben extends southeastward into the An Nafud.

An unnamed fault with a large amount of displacement near the northeastern corner of the Thaniyat Turayf quadrangle is part of the Wadi as Sirhan graben complex (cross-section A-A', plate 1). This fault is downthrown to the east and has an estimated displacement of about $800 \mathrm{~m}$. Its continuation southeastward is not indicated in the field, on aerial photographs, or Landsat imagery, but it may connect with the northwest-trending Al Jayb fault, located in the Al Jawf quadrangle to the east of the Thaniyat Turayf quadrangle.

The approximate axis of the Wadi as Sirhan graben trends northwest across the northeastern quadrant of the map area, and the northeastern boundary fault of the Wadi as Sirhan graben complex intersects the extreme northeast corner of the quadrangle.

Linear features, or lineaments (seen as straight lines on aerial photographs and Landsat imagery), normal faults, and grabens occur along the east-central border area of the quadrangle. Trends of the lineaments and faults range from approximately N. $10^{\circ}$ W. to N. $30^{\circ}$ W. and N. $10^{\circ}$ E. to N. $35^{\circ}$ E. Displacement along the faults and grabens is $6-30 \mathrm{~m}$, as indicated by the banks and scarps formed by the upthrown fault blocks. A series of north-northwest-trending lineaments (possibly caused by faulting) are seen along the Ja'alat ash Shahba and Ja'alat as Sawda escarpments; in the same area, there is a narrow isolated zone of steeply dipping, tightly folded rocks of the Jauf and Tawil formations. This zone commences west of Umm Nukhaylah and continues east-southeastward for about $20 \mathrm{~km}$. The area west of Umm Nukhaylah contains steep south-dipping beds of the Jauf and Tawil Formations that are apparently overturned and are unconformably over-lain by flat-lying beds of the Cretaceous and Tertiary Zallum and Kuwaykabah members. The Jauf Formation has not been preserved east of Umm Nukaylah, but in the Abraq al Hayq area, the Tawil sandstone is tightly folded and has steep dips to the north and south.

West of the Wadi as Sirhan graben complex, there are many northwesttrending lineaments and faults that are about $20 \mathrm{~km}$ long. West of the Al Huj area 
and south of the Thaniyat escarpment, faults and lineaments form long, narrow sandstone ridges. The ridges trend from N. $25^{\circ} \mathrm{W}$. to $\mathrm{N} .45^{\circ} \mathrm{W}$. and range in height from 9 to $15 \mathrm{~m}$. The dip of the beds in the sandstone ridges ranges from $10^{\circ} \mathrm{W}$. to vertical or overturned, whereas the beds on either side of the ridges are nearly flat lying and exhibit no indication of faulting. In most cases, the east sides of the ridges form a gentle scarp and the west sides constitute a dip slope. A possible model for the origin of the sandstone ridges is provided by analogy with the inferred origin of fine joint fractures observed elsewhere in the study area. The fractures are filled by sandy calcareous material that resists erosion more than the enclosing rock, with the result that the joint-fill material stands up as small ridges above the surface of the surrounding rock, revealing the joint pattern. Since the sandstone ridges of the western part of the map area reveal the macrojoint pattern in much the same way, it is conceivable that the sandstone ridges originated in a similar fashion, albeit on a larger scale. Normal faults occur in the same area, as well as a few long, narrow grabens. In the southwestern part of the quadrangle, lineaments mostly trend $\mathrm{N}$. $60-70^{\circ}$ E. and form a second set of regional fractures or macrojoints.

North-northwest-trending lineaments, faults, and grabens also occur in the phosphate-bearing Southwestern Area in the northwestern part of the quadrangle. Faults control the orientation of several large wadis in the Southwestern Area and offset the rocks along the Thaniyat escarpment. The Al Qasimah fault system extends through the central part of the Southwestern Area and is the boundary between a highly dissected plateau to the west and low-lying hilly terrain to the east (Smith, 1983; Griffin and others, 1984). Al Qasimah faults intersect the Thaniyat escarpment just west of the USGS adit (plate 1) and throw down the Thaniyat Phosphorite member about $30 \mathrm{~m}$ to the east. A series of stratigraphic sections measured along the escarpment record numerous faults (including step faults downthrown to the east), grabens, and horsts, all of which disrupt the continuity of the Thaniyat phosphate beds (Griffin and others, 1984, fig. 16). The maximum offset of the beds caused by faulting is about $30 \mathrm{~m}$.

A circular structure about $1.5 \mathrm{~km}$ in diameter and containing concentric rings of outward-dipping beds is located just south of the Ja'lat as Sawda escarpment, near the center of the study area. The center of the structure contains rocks of the Tawil Formation; the outer beds are made up of rocks of the overlying Jauf Formation. This circular structure resembles a pingo of glacial origin, but Saudi Arabian glaciers are not known to have existed later than the Early Silurian (Vaslet, 1987). The structure may have been caused by a buried igneous plug. Whatever its cause, it is unique to the quadrangle.

Faulting in the map area began prior to the Late Cretaceous and was followed by regional erosion of the older rocks. Rejuvenation of faulting occurred in the Late Cretaceous at the onset of the destruction of the Tethys seaway, a result of orogenic movements that continued at least until the Late Tertiary (Alpine orogeny) at the onset of the rift-fault systems of Africa and the Red Sea (Powers and others, 1966). 
The fault pattern of the quadrangle intersects the entire stratigraphic section from Silurian to Miocene rocks and is known to cut the Quaternary flood basalts in the quadrangle to the north of the Thaniyat Turayf quadrangle. Growth faulting and the rejuvenation of older faults may still be in progress.

\section{ECONOMIC GEOLOGY \\ Phosphorite}

\section{Thaniyat Phosphorite Member}

The Thaniyat Phosphorite member in the Southwestern Area is exposed along the Thaniyat escarpment and dips about 1 degree northeastward into the subsurface from the escarpment face. The member is located at a depth of $133 \mathrm{~m}$ in drill hole $P$ 48 on the east side of the Southwestern Area. The P48 drill hole contains an 8-m section of chert, sandstone, and both friable and calcareous phosphate pellets of the Thaniyat Phosphorite member (Ryder and Kluyver, 1983). After six boreholes were drilled at a selected area on top of the Thaniyat escarpment called "West Thaniyat" (lat $29^{\circ} 41^{\prime}-29^{\circ} 48^{\prime}$ N., long $37^{\circ} 51^{\prime}-37^{\circ} 58^{\prime}$ E.; Meissner, 1967), it was found that the Thaniyat Phosphorite member is 26-98 $\mathrm{m}$ deep and 2.1-4.9 $\mathrm{m}$ thick (Meissner and Ankary, 1972b). The average thickness and grade of phosphorite in the member at West Thaniyat is $1.65 \mathrm{~m}$ and 23 percent $\mathrm{P}_{2} \mathrm{O}_{5}$ respectively; estimated resources are $190,000,000 \mathrm{t}$.

The Graenges International Mining Company of Stockholm, Sweden, in a joint venture with Petromin of Saudi Arabia, conducted a detailed investigation of West Thaniyat (referred to by Graenges as the "Western Deposit Area") that included a more extensive drilling program, from mid-1977 to March, 1979. Their work resulted in a phosphorite resource estimate of $160,000,000 \mathrm{t}$ at an average grade of 21.5 percent $\mathrm{P}_{2} \mathrm{O}_{5}$. During the same period, Petromin-Graenges also investigated a somewhat smaller area north of the Thaniyat Turayf pass referred to as the "Eastern Deposit Area," in which an estimated 34,000,000 $t$ of phosphorite resource at an average grade of 24 percent $\mathrm{P}_{2} \mathrm{O}_{5}$ was reported. A comprehensive mining-feasibility study of the Thaniyat phosphorite conducted by Petromin-Graenges (unpublished data) concluded that, although the technical problems of underground mining and beneficiation of the ore could be solved, the cost of doing so rendered the project unattractive at present and in the near future.

Riofinex estimated phosphorite resources for a narrow strip of land along the western edge of the Southwestern Area that extends south from near the Jordan border in the Wadi as Sirhan quadrangle to the western end of the Thaniyat escarpment. This area is about $8 \mathrm{~km}$ wide and $45 \mathrm{~km}$ long and contains hypothetical resources of $344,000,000 \mathrm{t}$ with an average grade of 26.28 percent $\mathrm{P}_{2} \mathrm{O}_{5}$ and speculative resources of $440,000,000 t$ with an average grade of 26.25 percent $\mathrm{P}_{2} \mathrm{O}_{5}$. 
These estimates are based on only two drill holes that intersected three 1-m-thick phosphorite beds (maximum grade of 26.63 percent $\mathrm{P}_{2} \mathrm{O}_{5}$ ), and although data from these holes meet the criteria for hypothetical- and speculative-resource categories, the estimates should not be given too much emphasis (Riddler and others, 1986).

\section{Ghinah Phosphorite Member}

The Ghinah Phosphorite member crops out in many parts of the Southwestern Area and represents a significant episode of phosphatization. However, the phosphorite beds are too thin (less than $0.3 \mathrm{~m}$ ) and of too low a grade (less than 18 percent $\mathrm{P}_{2} \mathrm{O}_{5}$ ) to be an economic resource (Riddler and others, 1986).

\section{Oil ANd GaS}

Favorable indications for the origin and accumulation of oil and natural gas in the Wadi as Sirhan graben complex have been described for the Turayf and Wadi as Sirhan quadrangles to the north of the Thaniyat Turayf quadrangle (Meissner and others, 1987, 1989), and these conditions are believed to continue into the map area. About $850 \mathrm{~m}$ of marine rocks (potential hydrocarbon source rocks) were penetrated in the Aramco S-460 drill hole located in Wadi as Sirhan a few kilometers to the north of the map area. About $1,000 \mathrm{~m}$ of marine shale was penetrated in the $\mathrm{Al}$ Adari water well located in Wadi as Sirhan east of the map area (Aramco, unpublished data). The presence of potential source rocks coupled with conditions favorable to the accumulation of oil and natural gas in faulted areas of the Wadi as Sirhan graben are attractive incentives for future exploration.

\section{DATA STORAGE}

\section{Data File}

All field and laboratory data used in the preparation of this report, including petrographic descriptions, sample-site locations, thin sections, field notebooks, and results of geochemical analyses are stored in Data File USGS-DF-08-2 (on file in the Jeddah office of the U.S. Geological Survey Saudi Arabian Mission) and in Riofinex Data File RF-DF-00-5.

\section{Mineral Occurrence Documentation System}

Updated information was added to the Mineral Occurrence Documentation System (MODS) for Thaniyat (general), file number 00367, a new mineral occurrence. 


\section{REFERENCES CITED}

Bayliss, D. D., 1981, Lithostratigraphy and biostratigraphy of the Sirhan-Turayf phosphate area: Saudi Arabian Deputy Ministry for Mineral Resources Open-File Report RF-OF-01-25, 131 p.

-.-.-.-.-, 1982, Sirhan-Turayf phosphate project: Lithostratigraphy and biostratigraphy of outcrop and borehole sections (P-Series holes and USGS WT-borehole sections), Thaniyat and Wadi Sirhan Areal Subdivisions: Saudi Arabian Deputy Ministry for Mineral Resources Open-File Report RF-OF-02-27, 165 p.

1983, A review of the lithostratigraphy and biostratigraphy of the Sirhan-Turayf phosphate area: Saudi Arabian Deputy Ministry for Mineral Resources Open-File Report RF-OF-03-6, 33 p.

Bigot, M., 1970, Geology of the Tabuk and Jauf Formations in the Wadi Fajr area: Saudi Arabian Directorate General of Mineral Resources Open-File Report 70 JED 28, 18 p.

Bramkamp, R. A., Brown, G. F., Holm, D. A., and Layne, N.,M., 1963, Geology of the Wadi as Sirhan quadrangle, Kingdom of Saudi Arabia: U.S. Geological Survey Miscellaneous Geological Investigations Map I-200A, scale 1:500,000.

Capetta, H., and Riddler, G. P., 1985, Age determination on a selection of fish remains from phosphorite beds in the Sirhan-Turayf region: Riofinex Internal Report in Data File RF-DF-00-05.

Cathcart, J. B, 1966, Phosphate deposits in the Jawf-Sakakah basin, Kingdom of Saudi Arabia, Part III, Preliminary observations on the texture and composition: U. S. Geological Survey Technical Letter 83, 23 p. U.S. Geological

Clark-Lowes, D. D, 1980, Sedimentology and mineralization potential of the Saq and Tabuk Formations, Qassim District: Saudi Arabian Directorate General of Mineral Resources Open-File Report 767, 88 p.

Futyan, A., and Nicholson, C. A., 1979, Saudi Arabia phosphate stratigraphic study, stratigraphical, petrographical, and micropaleontological studies of 195 field samples from the Wadi Sirhan basin, northern Saudi Arabia: Directorate General of Mineral Resources, Kingdom of Saudi Arabia, Riofinex Geological Mission, RFO-1979-41, v. I and II, unnumbered pages.

Griffin, M.B., Farasani, A.M., Watson, A.D., Dini, S.M., and Riddler, G.P., 1984, Sirhan-Turayf phosphate project: geology of the phosphorite resources of the Southwestern Area: Saudi Arabian Deputy Ministry for Mineral Resources Open-File Report RF-OF-04-21, 70 p. 
Kluyver, H. M., Bege, V. B., Smith, G. H., Ryder, J. M., and van Eck, Marcel, 1981, Sirhan-Turayf Project: results of work carried out under the Phosphate Agreement, 29 Dhual Hijjah 1398H-30 Jumad Thani 1401H (29 November 1978G-4 May 1981G): Saudi Arabian Deputy Ministry for Mineral Resources Technical Record RF-TR-01-5, 77 p.

Lozej, G.-P., 1983, Geological and geochemical reconnaissance exploration of the cover rocks in northwestern Hijaz--initial results and recommendations: Saudi Arabian Deputy Ministry for Mineral Resources Open-File Report RF-OF-03-2, 135 p.

1984, Sirhan-Turayf phosphate project, a contribution to the regional stratigraphy: Saudi Arabian Deputy Ministry for Mineral Resources Open-File Report RF-OF-04-15, 82 p.

Matzko, J. J., and Naqvi, I. M., 1982, Geodes from Saudi Arabia: Deputy Ministry for Mineral Resources Qpen-File Report USGS-QF-02-66, 30 p.

Meissner, C. R., Jr., 1967, Phosphate rock at West Thaniyat, Sirhan-Turyaf (Jawf-Sakakah) Basin, Kingdom of Saudi Arabia: U. S. Geological Survey Technical Letter 94,8 p. U.S. Geological Suryey Open-File Report (IR)-SA-94,

Meissner, C. R., Jr. and Ankary, Abdullah, 1971, Geologic map of the Thaniyat Turayf quadrangle, northwestern Saudi Arabia: Saudi Arabian Directorate General of Mineral Resources Mineral Investigations Map MI-25, scale $1 ; 25,000$.

1972a, Geologic map of the Kutaybat Nasir quadrangle, northwestern Saudi Arabia: Saudi Arabian Directorate General of Mineral Resources Mineral Investigations Map MI-24, scale 1:25,000.

1972b, Phosphorite deposits in the Sirhan-Turayf basin, Kingdom of Saudi Arabia: Saudi Arabian Directorate General of Mineral Resources Mineral Resources Report of Investigations 2, 27 p.

Meissner, C. R., Jr., Griffin, M. B., Riddler, G. P., van Eck, Marcel, Aspinall, N. C., Farasani, A. M., and Dini, S. M., 1989, Preliminary geologic map of the Wadi As Sirhan quadrangle, Sheet 30C, Kingdom of Saudi Arabia: Saudi Arabian Deputy Ministry for Mineral Resources Open-File Report USGS-OF-08-3.

U.S. Geological Survey Open-File Report (in press)

Meissner, C. R., Jr., Mytton, J. W., Riddler, G. P., van Eck , Marcel, Aspinall, N. C., Farasani, A. M., and Dini, S. M., 1986, Preliminary geologic of the Ash Shuwayhitiyah quadrangle, Sheet 30 D, Kingdom of Saudi Arabia: Saudi Arabian Deputy Ministry for Mineral Resources Open-File Report USGSOF-06-1,26 p. U.S. Geological Survey Open-File Report (in press) 
Meissner, C. R., Jr., Riddler, G. P., van Eck, Marcel, Aspinall, N. C., Farasani, A. M., and Dini, S. M., 1987, Preliminary geologic map of the Turayf quadrangle, Sheet $31 \mathrm{C}$, and part of the An Nabk quadrangle, Sheet $31 \mathrm{~B}$, Kingdom of Saudi Arabia: Saudi Arabian Deputy Ministry for Mineral Resources OpenFile Report USGS-OF-07-3 (IR 773), 28 p. U.S. Geological Survey Open-

Mytton, J. W., 1966, Phosphate deposits in the Jawf-Sakakah basin, Kingdom of Saudi Arabia, Part II, Thaniyat Turayf and Quraymiz, U. S. Geological Survey Technical Letter 74, 19 p. U.S. Geological Survey Open-File Report (IR) SA-74.

PETROMIN-Graenges International Mining, 1980, Thaniyat phosphate project: Final Exploration Report - 6 vols., Stockholm.

Powers, R. W., 1968, Saudi Arabia-Lexique stratigraphique internationale v.3, f.10, b. 1, Paris, 177 p.

Powers, R. W., Ramirez, L. F., Redmond, C. D., and Elberg, E. L., Jr., 1966, Geology of the Arabian Peninsula; sedimentary geology of Saudi Arabia: U. S. Geological Survey Professional Paper 560-D, 147 p.

Riddler, G. P., Khallaf, H. M., and Farasani, A. M., 1983, Exploration for phosphate in the Sirhan-Turayf region, northwest Saudi Arabia: Saudi Arabian Deputy Ministry for Mineral Resources Open-File Report RF-OF-03-22, 12 p.

Riddler, G. P., and van Eck, Marcel, 1984, Sirhan-Turayf phosphate project progress report for 1402-1403 AH program (August 1982-August 1983): Saudi Arabian Deputy Ministry for Mineral Resources Open-File Report RF-OF-04-6, 38 p.

Riddler, G. P., van Eck, Marcel, Aspinall, N. C., McHugh, J. J., Griffin, M. B., and Farasani, A. M., 1984, Sirhan-Turayf phosphate project, lithostratigraphy of the Turayf group: Saudi Arabian Deputy Ministry for Mineral Resources Open-File Report RF-OF-04-2, 40 p.

Riddler, G. P., van Eck, Marcel, Aspinall, N. C., McHugh, J. J., Parker, T. W. H., Farasani, A. M., and Dini, S. M., 1986, An assessment of the phosphate resource potential of the Sirhan-Turayf region: Saudi Arabian Deputy Ministry for Mineral Resources Technical Record RF-TR-06-2, 152 p.

Ryder, J. M., and Kluyver, H. M., 1983, Detailed logs and cross sections, phase 1 drilling, P1-P86, Sirhan-Turayf phosphate area: Saudi Arabian Deputy Ministry for Mineral Resources Open-File Report RF-OF-03-12.

Smith, G. H., 1983, Reconnaissance exploration for phosphate in the Thaniyat-Quraymiz district: Saudi Arabian Deputy Ministry for Mineral Resources Open-File Report RF-OF-03-3, 69 p. 
Torrent, H., 1976, Preliminary investigation of the availability of water supplies for the phosphate deposits of West Thaniyat and Turayf: Saudi Arabian Directorate General of Mineral Resources Report BRGM 76 Jed 1, 18 p.

van Eck, Marcel, 1985, Sirhan-Turayf phosphate project: Lithostratigraphy of the Aruma Formation: Saudi Arabian Deputy Ministry for Mineral Resources Open-File Report RF-OF-05-23, 26 p.

Vaslet, Denis, 1987, Early Paleozoic glacial deposits in Saudi Arabia, a lithostratigraphic revision: Saudi Arabian Deputy Ministry for Mineral Resources Technical Record BRGM-TR-07-1, 21 p. 